Bicarbonate Impact on U(VI) Bioreduction in a Shallow Alluvial Aquifer

Philip E. Long ${ }^{1}$, Kenneth H. Williams ${ }^{l}$, James A. Davis ${ }^{l}$, Patricia M. Fox ${ }^{1}$, Michael J. Wilkins ${ }^{2 \S}$, Steven B. Yabusaki ${ }^{2}$, Yilin Fang ${ }^{2}$, Scott R. Waichler ${ }^{2}$, Elena S.F. Berman ${ }^{3}$, Manish Gupta ${ }^{3}$, Darrell P. Chandler ${ }^{4}$, Chris Murray ${ }^{2}$, Aaron D. Peacock ${ }^{5}$, Ludovic Giloteaux ${ }^{6}$, Kim M. Handley ${ }^{7 \#}$, Derek R. Lovley ${ }^{8}$, and Jillian F. Banfield 7

${ }^{1}$ Lawrence Berkeley National Laboratory, Berkeley, CA 94720, USA

${ }^{2}$ Pacific Northwest National Laboratory, Richland, WA 99352, USA

${ }^{3}$ Los Gatos Research, Mountain View, CA 94041-1529

${ }^{4}$ Akonni Biosystems, Inc., 400 Sagner Avenue, Suite 300, Frederick, MD 21701

${ }^{5}$ Haley \& Aldrich, Inc., 501 River St. \#100, Greenville, SC 29601

${ }^{6}$ Department of Molecular Biology and Genetics, 321 Biotechnology Building, Cornell University, Ithaca, NY 14853

${ }^{7}$ Earth and Planetary Science and Environmental Science, Policy, and Management, University of California-Berkeley, Berkeley, CA 94720

${ }^{8}$ Department of Microbiology, University of Massachusetts, Amherst, MA 01003

${ }^{\S}$ Current address: School of Earth Sciences and Department of Microbiology,

The Ohio State University, Columbus, OH, 43210

\#Current address: Department of Ecology and Evolution

University of Chicago, Chicago, IL 60637

*Corresponding author e-mail: pelong@lbl.gov; phone: 509.531.2987

Submitted to Geochimica et Cosmochimica Acta 


\title{
Bicarbonate Impact on U(VI) Bioreduction in a Shallow Alluvial Aquifer
}

\begin{abstract}
Field-scale biostimulation and desorption tracer experiments conducted in a uranium (U) contaminated, shallow alluvial aquifer have provided insight into the coupling of microbiology, biogeochemistry, and hydrogeology that control U mobility in the subsurface. Initial experiments successfully tested the concept that Fe-reducing bacteria such as Geobacter sp. could enzymatically reduce soluble U(VI) to insoluble U(IV) during in situ electron donor amendment (Anderson et al. 2003, Williams et al. 2011). In parallel, in situ desorption tracer tests using bicarbonate amendment demonstrated ratelimited U(VI) desorption (Fox et al. 2012). These results and prior laboratory studies underscored the importance of enzymatic U(VI)-reduction and suggested the ability to combine desorption and bioreduction of U(VI). Here we report the results of a new field experiment in which bicarbonate-promoted uranium desorption and acetate amendment were combined and compared to an acetate amendment-only experiment in the same experimental plot. Results confirm that bicarbonate amendment to alluvial aquifer sediments desorbs U(VI) and increases the abundance of Ca-uranyl-carbonato complexes. At the same time, the rate of acetate-promoted enzymatic U(VI) reduction was greater in the presence of added bicarbonate in spite of the increased dominance of Ca-uranylcarbonato aqueous complexes. A model-simulated peak rate of $\mathrm{U}(\mathrm{VI})$ reduction was $\sim 3.8$ times higher during acetate-bicarbonate treatment than under acetate-only conditions. Lack of consistent differences in microbial community structure between acetatebicarbonate and acetate-only treatments suggest that a significantly higher rate of U(VI) reduction in the bicarbonate-impacted sediment may be due to a higher intrinsic rate of microbial reduction induced by elevated concentrations of the bicarbonate oxyanion. The findings indicate that bicarbonate amendment may be useful in improving the engineered bioremediation of uranium in aquifers.
\end{abstract}




\section{Introduction}

The importance of direct enzymatic or microbially-mediated reduction of soluble U(VI) has been established by extensive laboratory and field experiments (Gorby and Lovley, 1992; Hwang et al., 2009; Kelly et al., 2008; Kostka et al., 2009; Lovley et al., 1991; Newsome et al., 2014; Suzuki et al., 2005; Tang et al., 2013; Wu et al., 2006; Wu et al., 2010; Xu et al., 2010), including those conducted in, or with material from, an alluvial aquifer at Rifle, CO, USA (Anderson et al., 2003; Bopp et al., 2010; Chandler et al., 2010; Druhan et al., 2014a; Druhan et al., 2014b; Fang et al., 2009a; Holmes et al., 2007b; Komlos et al., 2008; Williams et al., 2011). Other studies have likewise established the importance of bicarbonate concentrations on the desorption of U(VI) from subsurface sediments (Curtis et al., 2004; Davis et al., 2004; Hyun et al., 2009), and the slowing of bioreduction when ternary Ca-uranyl-carbonato aqueous species dominate U(VI) aqueous speciation (Dong and Brooks, 2006; Stewart et al., 2007). The idea of coupling U(VI) desorption using bicarbonate and microbial reduction of U(VI) was first proposed by Phillips et al. (1995) based on laboratory desorption of U(VI) from a variety of sediment types followed by bioreduction using Desulfovibrio desulfuricans. Subsequent field research at Rifle suggested the likely efficacy of such an approach under in situ aquifer conditions (Ortiz-Bernad et al., 2004a). An in situ bicarbonate-only desorption experiment at the Rifle site (referred to as "Little Rusty") confirmed that dissolved U(VI) concentrations increased significantly (1.2-2.6-fold above background levels), resulting from increases in bicarbonate alkalinity from injectate solution and $\mathrm{Ca}$ concentrations due to cation exchange (Fox et al., 2012). Earlier field experiments also conducted at the Rifle site (especially one referred to as "Big Rusty") had indicated that the predominance of Ca-uranyl-carbonato species did not prevent significant U(VI) bioreduction, which bolstered the idea that bicarbonate desorption could be combined with down-gradient, acetate-induced biostimulation to increase the mass of U(VI) reduced in a the subsurface aquifer (Williams et al., 2011). The field experimental results from Big Rusty were also the focus of an extensive reactive transport modeling effort (Yabusaki et al., 2011) that provided the underlying biogeochemical reaction network used in modeling for this paper.

The objectives of this study (dubbed "Super 8") were to: (1) confirm and extend previous uranium desorption results using bicarbonate (Fox et al., 2012); (2) quantify uranium mobility during acetate amendment under conditions of varying alkalinity and where microbial iron reduction is the dominant metabolic process; (3) assess the extent to which higher alkalinity values would impact U(VI) speciation and the rate of enzymatic uranium reduction; and (4) compare the post-amendment rebound of U(VI) with and without desorption of U(VI) by bicarbonate amendment. Here we emphasize the conservative tracer, biogeochemistry, microbiology, and U(VI) reduction results from the bicarbonate-acetate and acetate-only parts of the Super 8 field experiment. Other studies conducted as part of the same experiment are reported elsewhere (Alessi et al., 2014; Bao et al., 2014; Chandler et al., 2013; Handley et al., 2014; Holmes et al., 2013a; Holmes et al., 2013b; Shiel et al., 2013). These studies investigated selected aspects of the 
experiment, including reactive transport modeling, microbiology of selected wells, gene expression, $\mathrm{U}$ isotopic shifts during bioreduction, and predation by protists on bacteria during biostimulation. Here, we combine biogeochemistry, microbiology, conservative tracer, and modeling of $\mathrm{U}(\mathrm{VI})$ reduction from the bicarbonate-acetate and acetate-only treatments, to demonstrate that bicarbonate both increases the pool of uranium available for acetate-induced $\mathrm{U}(\mathrm{VI})$ reduction and also impacts the microbial community in a way that enhances the intrinsic rate of $\mathrm{U}(\mathrm{VI})$ bioreduction.

\section{Material and methods}

Site location, site geohydrology, analytical methods, and materials are described elsewhere (Fox et al. 2012, Williams et al. 2011 and references therein). For this experiment, we installed a new set of 34 wells in 2010 (Plot C) in a previously unstimulated portion of the Rifle site (Fig. 1) using the rotary sonic drilling method. The well layout was designed to combine bicarbonate and acetate amendment on one side of Plot $\mathrm{C}$ with the other side reserved solely for acetate addition. The timing of amendments was designed to span the period when microbial Fe reduction was the dominant terminal electron accepting process. However, the target initial bicarbonate concentration $(\sim 30$ $\mathrm{mM})$ in the aquifer was chosen to mimic that produced during biostimulation when sulfate reduction is at a maximum. In field experiments at the Rifle site, acetate amendment initially stimulates Fe-reducing microbial populations that transitions to dominance of sulfate reducers after about 3 weeks (Williams et al. 2011), producing greater bicarbonate concentrations. Stoichiometrically, the background concentration of $\sim 10 \mathrm{mM}$ of sulfate reduced yields a $20 \mathrm{mM}$ increase in bicarbonate above the background concentration of $\sim 10 \mathrm{mM}$. However, Fe-reducers continue to reduce metals even during dominance of sulfate reduction hence the desire to understand the impact of increased bicarbonate on Fe-reducing microbial populations.

Wells were emplaced to a depth corresponding to the contact between the aquifer alluvium and the largely impermeable Wasatch formation ( 6 to $7 \mathrm{~m}$ below ground surface, see DOE (1999) for additional information on geologic setting). Wells were typically screened over the entire saturated thickness of the aquifer ( $\sim 3$ to $7 \mathrm{~m}$ below ground surface). Selected wells were designed to collect samples at 3 discrete depths.

Deuterium $\left({ }^{2} \mathrm{H}\right.$ or $\left.\mathrm{D}\right)$ was used as a conservative tracer for the bicarbonate injectate and quantified (as water with one hydrogen $(\mathrm{H})$, one D and one oxygen (O) or HDO) with a liquid water isotope instrument (Los Gatos Research Inc.) as described in Berman et al. (2009) except for differences detailed in Supplemental Information (SI). NaBr was used as a conservative tracer for the acetate $\left(\mathrm{CH}_{3} \mathrm{COONa} \cdot 3 \mathrm{H}_{2} \mathrm{O}\right)$ amendment and analyzed by ion chromatography as described elsewhere (Williams et al., 2011).

2.1 Experimental Design and Timeline. The experimental objectives required that groundwater amendments (acetate and sodium bicarbonate) be introduced at spatially distinct locations and timed such that acetate followed bicarbonate desorption of U(VI) on the bicarbonate-acetate side of the experiment. To achieve these objectives, groundwater from a location with no previous biostimulation (well \#655) was pumped into two separate tanks, 1) a $6000 \mathrm{~L}$ high-density polyethylene (HDPE) tank for 
bicarbonate plus deuterium as a tracer and 2) a $2120 \mathrm{~L}$ stainless steel tank for acetate and $\mathrm{NaBr}$ as a tracer. $\mathrm{NaHCO}_{3}$ (Fisher Scientific) and 70\% $\mathrm{D}_{2} \mathrm{O}$ (Cambridge Isotope Laboratories, Inc.) were added to the HDPE tank to achieve a $\delta \mathrm{D}$ of tank water of $\sim 380 \%$ o and a bicarbonate concentration of $50 \mathrm{mM}$. The HDPE tank was sparged with $\mathrm{CO}_{2}$ to prevent extensive oxygenation of stored groundwater, and achieve a $\mathrm{pH}$ of $\sim 7$. Tank contents were circulated for 4 days (first tank) and 2 days (second tank) to enhance mixing and dissolution. The HDPE tank remained open to atmosphere over the injection period (Table 1), with a 30-45 min daily $\mathrm{CO}_{2}$ sparging to maintain $\mathrm{pH}$ at $7.1 \pm 0.2$. The stainless steel tank (2120L) was amended with $50 \mathrm{mM} \mathrm{CH}{ }_{3} \mathrm{COONa}_{3} 3 \mathrm{H}_{2} \mathrm{O}($ Sigma Aldrich) and $20 \mathrm{mM} \mathrm{NaBr}$ (Sigma Aldrich) while sparging with $\mathrm{N}_{2}$. The tank remained sealed under $\mathrm{N}_{2}$ headspace during the injection period.

Both injectates were introduced to the aquifer using separate sets of boreholes oriented approximately orthogonal to groundwater flow direction and spaced at $1.5 \mathrm{~m}$ intervals (Fig. 1). Tank contents were introduced to each injection well at 3.5 and $5.5 \mathrm{~m}$ below ground surface at rates of $180 \mathrm{~L} \mathrm{well}^{-1}$ day $^{-1}$ (bicarbonate tank; 3 wells, CA01, CA02, CA03) and 16 $\mathrm{L}^{-1}$ wel $^{-1}$ day $^{-1}$ (acetate tank; 10 wells, CG01-CG10). Injection of acetate/bromide was interrupted for ca. 5 days between the first and second filling of the acetate tank (Table 1). Cross-well mixing was used to disperse the injectates across the zone of injection, with peristaltic pumps circulating fluids $\left(0.7 \mathrm{~L} \mathrm{~min}^{-1}\right)$ between adjacent wells through HDPE tubes (Williams 2011). For both injectates, fluids from two wells (e.g. CA01 and CA03) were withdrawn from a depth of $6 \mathrm{~m}$ and injected simultaneously into an adjacent well (e.g. CA02) at a depth of $4 \mathrm{~m}$ to create head differences between adjacent wells. Water level elevations were monitored at 15-minute intervals in all injection wells using pressure transducers. Pump directions were changed daily such that individual wells served alternately as extraction and injection wells for cross-well mixing.

$\mathrm{NaHCO}_{3}(\sim 50 \mathrm{mM})$ was delivered to the aquifer through wells CA01-CA03, such that $\mathrm{NaHCO}_{3}$ entered the system upgradient of subsequent acetate amendment (Fig. 1). After injection, $\mathrm{HCO}_{3}{ }^{-}$was advected along the primary groundwater flow direction and intersected the region of acetate amendment in wells CG06-CG09. Wells CG01-CG05 were located in a region unimpacted by $\mathrm{HCO}_{3}{ }^{-}$. All of the $\mathrm{CG}$ wells (CG01- CG10) were used for injection of acetate and $\mathrm{NaBr}$.

2.2 Aqueous U(VI) Speciation calculations. Uranium(VI) speciation calculations were performed using the thermodynamic data published in Hyun et al. (2009) and the computer program FITEQL4 set to equilibrium mode (Herbelin and Westall, 1999). Most of the uranium thermodynamic data are consistent with the NEA database (Guillaumont et al., 2003) with the exception of Ca-uranyl-carbonato complexes and $\mathrm{Mg}$ uranyl-carbonato complex (Dong and Brooks, 2006; Dong and Brooks, 2008). Ionic strength corrections in FITEQL4 were made with the Davies equation.

2.3 Microbiological Analyses. Bicarbonate-acetate and acetate-only treatments were compared microbiologically by $16 \mathrm{~S}$ rRNA gene analysis of the groundwater. A $16 \mathrm{~S}$ rRNA-targeted gel element 'amplification' microarray (combining amplification, labeling and hybridization in a single closed microfluidic chamber) method was used, which 
targets 24 genera of dissimilatory metal-, sulfate- and nitrate- reducers (Chandler et al. 2013). The link between phylogeny and function in the microarray targets has been established via culture-based methods (see Andersen et al. (2010) and references therein). Total nucleic acid from 1-2 L groundwater was extracted from filter cartridges with a MoBio PowerSoil DNA Isolation Kit (Carlsbad, CA) following manufacturer's instructions. Three microliters of purified nucleic acid representing 30-60 mL equivalent of groundwater was processed in duplicate as described in detail elsewhere (Chandler et al., 2010).

Microbial groundwater communities from a select time point during peak Fe(III) reduction were further analyzed using clone library analysis. DNA was extracted from groundwater collected on 9/14/2010 from acetate-only and bicarbonate-acetate treatment wells CD04 and CD14, respectively, as previously described (Giloteaux et al., 2013). Briefly, 16S rRNA sequences were amplified using primers 338F (Lane et al., 1985) and 907R (Amann et al., 1990) and clone libraries were constructed with a TOPO TA cloning kit (Invitrogen, Carlsbad, CA) according to the manufacturer's instructions. One hundred and fifty plasmid inserts per clone library were sequenced with the universal M13F/M13R primer set.

DNA from sediment-attached microbial populations was also extracted from sediment collected during drilling of well CD04 as part of a different study (Handley et al., 2014). In short, freshly obtained Rifle aquifer sediment was first packed into flow through columns, and incubated within wells during acetate-amendment. DNA was extracted from homogenized sediment using PowerMax Soil DNA Isolation Kits (MoBio Laboratories, Inc., Carlsbad, CA, USA). 16S rRNA genes were amplified using the universal bacterial primers $27 \mathrm{~F}$ and 1492R, and gradient PCR (11 annealing temperature increments, $48-58^{\circ} \mathrm{C}$ ). Amplicons were fragmented to $\sim 300 \mathrm{bp}$ and paired-end libraries were constructed prior to sequencing on the HiSeq2000 platform (Illumina ${ }^{\circledR}$ Inc., San Diego, CA, USA). Quality trimmed reads (Q>3) were reconstructed into full-length sequences using the EMIRGE method (Miller et al., 2011; Miller et al., 2013).

2.4 Reactive Transport Modeling. Modeling of the Super 8 experiment is based on a simulation capability developed for prior Rifle field biostimulation experiments (Fang et al., 2009b; Li et al., 2010; Li et al., 2009; Yabusaki et al., 2007; Yabusaki et al., 2011), and relies heavily on model parameters developed for the 2008 Big Rusty acetate biostimulation field experiment (Williams et al., 2011). eSTOMP, a massively parallel processing, multifluid flow and multicomponent reactive transport subsurface simulator provided the framework and the high performance computing (HPC) infrastructure to address high spatial resolution and the complex biogeochemical processes involved in the field experiment as described below. Simulations covered a 70-day period to capture the time period that includes the focus of this paper, which is comparing reduction rates under acetate-only and bicarbonate-acetate conditions. The 70-day cutoff was thus chosen to capture the behaviors of interest while conserving HPC resources.

A large biogeochemical reaction network is required to model Rifle field experiments in part because of the broad range of uranium mobility that is sensitive to $\mathrm{pH}$, alkalinity, 
major ion chemistry, redox state and the surface reactivity of the subsurface sediments (Davis et al., 2002; Fox et al., 2012; Morrison et al., 1995). The modeling challenge is that products of the biostimulation (e.g., bicarbonate, Fe(II), U(IV), sulfide) can alter the geochemical conditions controlling uranium mobility (Fang et al., 2009b; Zhao et al., 2013). Using the Yabusaki et al. (2011) biogeochemical reaction network (i.e., stoichiometry, thermodynamics, and rate laws), we simulated the 2010 Super 8 field biostimulation experiment with 102 chemical species and 7 minerals addressing 3 microbially-mediated terminal electron accepting processes (i.e., Fe(III), U(VI), sulfate), and $\mathrm{Fe}(\mathrm{III})-$ and sulfate-reducing microorganisms and their biomass. Major ion chemistry, mineral reactions (i.e., calcite, siderite, goethite, magnetite, FeS, elemental sulfur, uraninite), surface complexation (i.e., $\mathrm{H}+, \mathrm{Fe}(\mathrm{II}), \mathrm{U}(\mathrm{VI})$ ), and ion exchange processes (i.e., $\mathrm{Ca}++, \mathrm{Mg}++, \mathrm{Na}+\mathrm{K}+$ ) were included. Ion exchange capacity and surface sites for U(VI) sorption were modified from the Yabusaki et al. (2011) model to provide an improved fit to the observed desorbed U(VI) and major cation concentrations, especially $\mathrm{Ca}++$ (see SI for additional details).

Two key assumptions in the model are 1) U(VI) aqueous species re-equilibrate, diffuse, or advect rapidly such that after formation or consumption of one species the equilibrium proportions for the local geochemical conditions are re-established rapidly, and 2) uraninite $\left(\mathrm{UO}_{2}\right)$ is the product of bioreduction of $\mathrm{U}(\mathrm{VI})$. Uranyl ion concentration is used in the bioreduction reaction and rate law. Since the uranyl ion concentration is small relative to the total aqueous $\mathrm{U}(\mathrm{VI})$ concentration, its inclusion instead of total U(VI) does limit the conversion rate. However, the kinetic reductive removal of uranyl ion from solution is rapidly restored via the equilibrium speciation of the remaining U(VI) in solution.

While monomeric (or non-crytalline) U(IV) is an important component of total U(IV) in bioreduced Rifle sediments (Alessi et al., 2014; Bargar et al., 2013; Cerrato et al., 2013), and Bargar et al. (2013) point out the need for reactive transport models that include monomeric $\mathrm{U}(\mathrm{VI})$ as bioreduction products, the lack of stability constants and uncertainty regarding biogeochemical controls for formation of monomeric U(IV) limit our ability to incorporate non-uraninite forms of U(IV) into the model. Uraninite is also assumed to be stable under subsurface conditions at Rifle that include low dissolved oxygen (typically $<0.2 \mathrm{mg} / \mathrm{l}$, Yabusaki et al., 2007) and based on in situ experiments at Rifle that show slow dissolution rates for uraninite (Campbell et al., 2011).

The geology in the well field (Plot C) is predominantly the sandy gravel lithofacies defined in Yabusaki et al. (2011) for an earlier field experiment at the site, the Big Rusty acetate biostimulation experiment conducted in the Summer and Fall of 2008. The lithofacies-based properties of the sandy gravel classification $(30 \mathrm{~m} / \mathrm{d}$ hydraulic conductivity, 0.230 porosity, $3.25 \mathrm{~m}^{2} / \mathrm{g}$ specific surface area) were therefore assumed. As in the simulation for the Big Rusty experiment, longitudinal and transverse dispersivity were $0.4 \mathrm{~m}$ and $0.04 \mathrm{~m}$, respectively (based on analysis of bromide tracer data, see Yabusaki et al. 2011).

The modeled subsurface domain is approximately $14 \mathrm{~m}$ downgradient by $18 \mathrm{~m}$ transverse by $6.5 \mathrm{~m}$ deep, and is represented by 209,664 grid cells with nominal grid spacing of 0.25 $\mathrm{m}$ laterally and $0.10 \mathrm{~m}$ vertically. The flow field and saturated thickness are driven by 
time-dependent water levels on the domain boundary, and bicarbonate and acetate solutions introduced at injection wells. The model boundary conditions are based on water level measurements over the 70-day simulation period. In all cases, it was assumed that the total injectate volume was distributed equally over the specified set of injection wells for the duration of the release, a reasonable assumption for a newly established well field in the Rifle alluvial aquifer (Yabusaki et al. 2007, Williams et al. 2011).

\section{Results}

Samples from $\sim 33$ wells were analyzed during the course of the field experiment; here we plot geochemistry results from three wells that show the results from different parts of the experiment: bicarbonate-only (well CU03), acetate-only (well CD01) and bicarbonateacetate (well CD14). Other wells exhibit similar trends depending on location in the experimental plot (experimental data for all wells are available at doi:10.1594/PANGAEA.830272). Observations are well matched by the reactive transport model (e.g., Fig. S-3). Bicarbonate-only well CU03 was located $\sim 1 \mathrm{~m}$ downgradient from the bicarbonate injection wells and $1 \mathrm{~m}$ upgradient from the acetate injection wells, such that it was exposed to the $\mathrm{NaHCO}_{3} /$ deuterium injection but minimally impacted by the $\mathrm{CH}_{3} \mathrm{COONa} / \mathrm{NaBr}$ injection. Sporadic, low concentrations of acetate and bromide were occasionally detected during sampling of well CU03, in part due to cycling of cross-well mixing within $\sim 1 \mathrm{~m}$ of the CG01-CG10 injection gallery. Wells CD01 and CD14 were both impacted by the acetate injection, with both wells located $\sim 2.5 \mathrm{~m}$ downgradient from the region of acetate injection (Fig. 1).

3.1 Groundwater quality parameters and conservative tracer breakthrough. The effects of bicarbonate and/or acetate on $\mathrm{pH}$, specific/electrical conductance, $\mathrm{Fe}$ (II) concentrations, and $\delta \mathrm{D}$ values are illustrated in Fig. S-1. As expected, breakthrough of deuterium was primarily observed downgradient from $\mathrm{NaHCO}_{3}$ injection wells $\mathrm{CA01-}$ CA03, with increased dilution observed between CU03 and CD14 (peak $\delta$ D $\approx 340 \%$ at CU03 vs. $\delta \mathrm{D} \approx 175 \%$ at $\mathrm{CD} 14)$. $\mathrm{A}+5 \%$ increase over baseline in $\delta \mathrm{D}$ was observed at CD01 (Fig. S-1; inset), something we attribute to the cross-well mixing process. A significant increase in HDO $(\delta \mathrm{D}$ of $>35 \%$ ) was observed in wells CU04, CD11-CD17 (as intended), as well as CD06, CD08, CD09, and CD10 (not shown). Such breakthrough is generally consistent with the predicted flow direction (175-180 azimuth from north), but the channel feature along the top of the Wasatch Formation may have impacted flow of the relatively dense deuterium-bearing injectate (see Fig. 1 for isopleths of the contact between the Wasatch and the alluvium). Overall the conservative tracers ( $\mathrm{D}$ and $\mathrm{NaBr}$ ) demonstrate that the injectates were distributed over the experimental domain as intended.

Irrespective of the injectate (acetate, bicarbonate, or both), $\mathrm{pH}$ values generally remained within the 7-7.5 range; the abrupt excursion $(\mathrm{pH}>7.5)$ observed in CU03 (bicarbonate only) accompanied a rapid rise in $\mathrm{pH}$ within the $\mathrm{NaHCO}_{3} / \mathrm{D}_{2} \mathrm{O}$ injection tank, which was eliminated by $\mathrm{CO}_{2}$ sparging. Changes in groundwater electrical conductivity (EC) tracked the delivery of both injectates $\left(50 \mathrm{mM} \mathrm{NaHCO}_{3}\right.$, and $50 \mathrm{mM} \mathrm{NaCH}_{3} \mathrm{COO}+20$ $\mathrm{mM} \mathrm{NaBr}$, Table 1), with the greatest increases over baseline values observed in wells that were impacted by the bicarbonate injection. EC increases observed at CD01 and 
other wells solely impacted by the $\mathrm{CH}_{3} \mathrm{COONa} / \mathrm{NaBr}$ injectate increased by $<40 \%$. Although the tank concentrations of the $\mathrm{CH}_{3} \mathrm{COONa} / \mathrm{NaBr}$ injectate were similar in ionic strength that of the bicarbonate tank, injection flow rates were different for the two tanks such that a greater in-well dilution occurred for the acetate-only injection. As a consequence, the peak total inorganic carbon (TIC) in CU03 (bicarbonate-only) is 50 $\mathrm{mM}$ (10 to $13 \mathrm{mM}$ of which is background TIC), whereas peak acetate plus the $\mathrm{NaBr}$ tracer in CD01 (acetate-only) is $\sim 9 \mathrm{mM}$. For bicarbonate-acetate (CD14) peak $\mathrm{TIC}+\mathrm{NaBr}+$ acetate is $\sim 40 \mathrm{mM}$, including $10-13 \mathrm{mM}$ TIC background. Considering the background TIC, the ionic strength from amendments in the acetate-only part of the experiment is $\sim 50 \%$ of that of bicarbonate-acetate.

Increases in ferrous iron concentration were observed downgradient from the region of acetate addition, reflecting the reduction of Fe(III) by acetate-stimulated, iron-reducing bacteria, consistent with all previous acetate injections at the Rifle site. Some increase in $\mathrm{Fe}$ (II) was observed at CU03, which was likely caused by cation exchange (50 $\left.\mathrm{mM} \mathrm{Na} \mathrm{Na}^{+}\right)$ releasing Fe(II) sorbed to surface exchange sites (Fox et al., 2013) and/or movement of stimulated groundwater from the vicinity of the acetate injection wells toward CU03 $(<1 \mathrm{~m})$.

3.2 Geochemical Changes Accompanying Bicarbonate Injection. Expanding upon previous $\mathrm{NaHCO}_{3}$ injection experiments at Rifle (Fox et al., 2012), geochemical changes in well CU03 were used to evaluate the impact of sustained (>20-day) levels of elevated $\mathrm{HCO}_{3}{ }^{-}$on uranium mobility, metals (V, Fe, Mn), as well as its impact on other exchangeable cations ( $\mathrm{Ca}, \mathrm{Mg}, \mathrm{K}, \mathrm{Na}$, Fig. 2). The results are consistent with an ion exchange model $(\mathrm{Ca}, \mathrm{Mg}, \mathrm{K})$ driven by the $\sim 70 \mathrm{mM} \mathrm{Na}$ in the amendments and enhanced desorption of uranium driven by the formation of stable aqueous species (e.g. $\mathrm{Ca}_{2} \mathrm{UO}_{2}\left(\mathrm{CO}_{3}\right)_{3}{ }^{0}$, the predominant $\mathrm{U}(\mathrm{VI})$ species under the conditions of the experiment). Abrupt and prolonged decreases in total Mn concentration are inferred to result from the low solubility of manganese carbonates.

Concentrations of multiple cations $(\mathrm{Ca}, \mathrm{Mg}$, and $\mathrm{K}$ ) fell below their pre-injection values once $\mathrm{NaHCO}_{3}$ injection ceased likely due to re-exchange of these cations with $\mathrm{Na}$ following the $\mathrm{NaHCO}_{3}$ flush. This effect was previously observed in the Little Rusty field experiment (Fox et al., 2012, 2013) and was simulated in an updated ion exchange model. Following injection, influx of groundwater from regions upgradient of the zone of $\mathrm{NaHCO}_{3}$ injection leads to removal of U(VI) from solution, as sorption sites for U(VI) species are re-filled. Once such sites are largely occupied, groundwater U(VI) concentrations rebound to pre-injection levels. In comparison with Little Rusty (Fox et al., 2012), both cation and U(VI) concentrations were generally slower to rebound following the Super 8 injection, likely due to the longer duration of the Super 8 injection (21d vs. $0.18 \mathrm{~d})$. In contrast, total $\mathrm{Fe}\left(\mathrm{Fe}_{\mathrm{TTL}}=\mathrm{Fe}^{\mathrm{II}}+\mathrm{Fe}^{\mathrm{III}}\right.$ ionic species) remained elevated following $\mathrm{NaHCO}_{3}$ injection, potentially the result of enhanced release of $\mathrm{Fe}$ (III) colloids ( $<45 \mu \mathrm{m}$ particle size) during injection (note that $\mathrm{Fe}(\mathrm{II})$ levels determined colorimetrically also fall to pre-injection values; Fig. S-1). 
3.3 Geochemical Changes Accompanying Acetate injection. The acetate-only portion of Plot $\mathrm{C}$ provided a direct comparison to the $\mathrm{NaHCO}_{3}$-impacted portion of the flow cell. Geochemical changes in well CD01 are shown in Figure 3. Desorption and re-sorption of exchangeable cations was also observed during and after $\mathrm{CH}_{3} \mathrm{COONa} / \mathrm{NaBr}$ injection, respectively, although the magnitude of the effect was less than that observed at CU03. The much smaller increase in ionic strength (and hence less injected $\mathrm{Na}^{+}$) accounts for the observed difference between the two sections of Plot $\mathrm{C}$. The presence of acetate, absence of amended bicarbonate, and resulting stimulation of metal-reducing bacteria also led to markedly different changes in concentrations of redox-sensitive metals in $\mathrm{CD} 01$ relative to CU03. The contrast was especially strong for $\mathrm{U}(\mathrm{VI})$ and $\mathrm{V}$, both of which can be reductively immobilized via enzymatic reduction by microorganisms (Lovley et al., 1991; Ortiz-Bernad et al., 2004b; Yelton et al., 2013). For $\sim 5$ to 7 days there was a slight increase in $\mathrm{U}(\mathrm{VI})$ and total $\mathrm{V}$ groundwater concentrations upon delivery of acetate to the wellbore region, followed by a rapid decrease in both U(VI) and total $\mathrm{V}$ in groundwater via reductive immobilization. A decrease in total $\mathrm{V}$ concentration in groundwater occurs immediately following the slight increase, similar to the observations made during the first Rifle field experiment (Ortiz-Bernad et al., 2004b), whereas removal of $\mathrm{U}(\mathrm{VI})$ was delayed by approximately 5 days. Groundwater $\mathrm{U}(\mathrm{VI})$ concentrations fell below the EPA's maximum contaminant level $(\mathrm{MCL}=0.126 \mu \mathrm{M})$ so long as acetate remained at detectable levels, as previously observed at the site (Williams et al., 2011). Once acetate injection ceased, U(VI) concentrations steadily rebounded due to the influx of $\mathrm{U}(\mathrm{VI})$-bearing groundwaters from upgradient locations and a slowing of microbial reduction in the absence of acetate addition. In contrast, total $\mathrm{V}$ concentrations in groundwater remained below the cleanup target concentration $(0.67 \mu \mathrm{M})$ far beyond the period where acetate fell below detectable levels (Ortiz-Bernad et al., 2004b; Yelton et al., 2013).

3.4 Combined Impact of Bicarbonate and Acetate Injection. As anticipated, the temporal behavior of exchangeable cations, metals, and uranium at CD14 was a combination of the processes observed at CU03 and CD01 (Fig. 4 and 5). Following an initial increase in $\mathrm{U}(\mathrm{VI})$ and $\mathrm{V}$ (as also observed in CU03), both metals were rapidly removed to very low concentrations. In contrast to the $\mathrm{CU}-03$ and $\mathrm{CD} 01$ locations, $\mathrm{U}(\mathrm{VI})$ concentrations remained below the MCL for $\sim 55$ days after acetate fell below detection. Total V concentration remained below the cleanup target at the point of exposure (DOE, 2001) of $6.48 \mu \mathrm{M}$ for more than 55 days after acetate levels fell below detection. Vanadium showed no indication of rebound, similar to the results obtained in well CD01 and observed in earlier experiments (Ortiz-Bernad et al., 2004b). Fe(II) reached greater maximum concentrations at CD14 than at CD01 (150 $\mu \mathrm{M}$ at CD01 vs. $225 \mu \mathrm{M}$ at CD14, Figs. 3 \& 4). While the impact of elevated $\mathrm{HCO}_{3}{ }^{-}$concentration on $\mathrm{Fe}(\mathrm{III})$ reduction is still uncertain, the significant increases in Fe(II) at CD14 relative to CD01 may simply be the result of a heterogeneous distribution of bioavailable Fe(III) in subsurface sediments or a combination of $\mathrm{Fe}$ (III) reduction and $\mathrm{Fe}$ (II) release through ion exchange (as observed in CU03). Uranium(VI) concentration increased two-fold at CU03 (ca. $0.65 \mu \mathrm{M}$ to $1.3 \mu \mathrm{M}$ ), whereas the increase at CD14 prior to acetate-induced $\mathrm{U}(\mathrm{VI})$ bioreduction was four-fold (ca. $0.5 \mu \mathrm{M}$ to $2 \mu \mathrm{M}$ ). The likely explanation is a longer transport distance (i.e., a larger volume of extracted sediments) over which bicarbonate is able to desorb 
$\mathrm{U}(\mathrm{VI})$. Specifically, the distance between the $\mathrm{NaHCO}_{3}$ injection wells and monitoring well CU03 is $\sim 1 \mathrm{~m}$ versus well CD14 which is $\sim 3.5 \mathrm{~m}$ from the $\mathrm{NaHCO}_{3}$ injection wells (cf. Fox et al. 2012).

There was a large difference in total inorganic carbon (TIC) concentration associated with $\mathrm{NaHCO}_{3}$ addition that resulted in a 6-fold difference in U(VI) desorption from sediments between CD01 and CD14 (Fig. 5). Regardless of TIC concentration (and by extension $\left.\left[\mathrm{HCO}_{3}{ }^{-}\right]\right)$, the apparent rates of $\mathrm{U}(\mathrm{VI})$ decrease $\left(\Delta \mathrm{U}(\mathrm{VI})_{\text {obs cond }} \mathrm{t}\right)$ associated with stimulated microbial activity were largely indistinguishable under high and low alkalinity and both wells reached relatively low values of U(VI) concentration (CD01: $0.03 \mu \mathrm{M}$ on day 42 and CD14: $0.06 \mu \mathrm{M}$ on day 53). The apparent rates are significant from the perspective of applied bioremediation, but understanding the underlying mechanisms and associated rates requires separating competing processes of aqueous speciation changes, desorption, bioreduction, and precipitation of new solid phases. We address this need by reactive transport modeling, establishing estimates of the actual rate of bioreduction of U(VI), as described in Section 3.8 Reactive Transport Modeling.

3.5 Uranium Rebound. One of the most pronounced differences between the bicarbonateacetate vs. the acetate-only parts of the experiment is the extent to which uranium rebounds after acetate injection ends (Fig. 5). Irrespective of the large increase in U(VI) concentrations associated with $\mathrm{HCO}_{3}{ }^{-}$-mediated desorption, uranium was not only removed rapidly from groundwater at the wells impacted by both bicarbonate-acetate, but it also remained at low levels (below the MCL) long after acetate injection ended (well CD14, Fig. 5C). The same was typically not true for locations exposed solely to acetate. There, uranium concentrations rebounded immediately or soon after acetate concentrations fell to levels below detection (well CD01, Fig. 5B). The most likely explanation for this phenomenon involves the extent to which re-sorption of advecting $\mathrm{U}(\mathrm{VI})$ occurs in areas where desorption was greatly enhanced by $\mathrm{NaHCO}_{3}$ injection. As noted above, movement of upgradient groundwater with U(VI) into the part of the bicarbonate-acetate part of the experiment is impacted by sorption onto newly vacant sorption sites; the same effect does not occur in wells close to the injection point (CD03, CD02, CD01, Figs. S-3 and 5B) and amended with acetate-only because U(VI) desorption was limited in the acetate-only part of the experiment (an increase in U(VI) of ca. $0.7 \mu \mathrm{M}$ to $0.9 \mu \mathrm{M}$, much less than for either CU03 or CD14).

Fox et al. (2012) demonstrated that there is a kinetic limitation to U(VI) desorption in Rifle sediments, likely due to a mass transfer limitation related to intragranular porosity of the sediments, a pore-size constraint on movement of U(VI) off mineral surfaces into groundwater. Kinetic limitation to U(VI) desorption likely caused a limited availability of sorbed inventories of U(VI) to microbial reduction (Ortiz-Bernad et al., 2004a). Were the sorbed pool of U(VI) not kinetically limited, a similar refilling of vacant sorption sites with U(VI) in upgradient groundwater (and the suppression of U(VI) concentrations) would have been expected under acetate-only conditions (e.g. at CD01). This is because removal of U(VI) from groundwater by bioreduction of U(VI), without the kinetic limitation, would result in additional desorption of U(VI). The rate of U(VI) desorption is apparently slow enough in the acetate-only region that the sorbed pool of U(VI) is not 
significantly reduced. Microbial reduction of the sorbed pool of $\mathrm{U}(\mathrm{VI})$ could be direct (bacteria directly reduce sorbed $\mathrm{U}(\mathrm{VI})$ to $\mathrm{U}(\mathrm{IV})$ ) or indirect (bacteria reduce dissolved $\mathrm{U}(\mathrm{VI})$ which is rapidly replenished by $\mathrm{U}(\mathrm{VI})$ desorption from sediments). Apparently neither of these mechanisms is significant under the in situ conditions at the Rifle site, otherwise longer-term suppression of $\mathrm{U}(\mathrm{VI})$ concentrations would be expected under acetate-only conditions. An important assumption here is that $\mathrm{U}(\mathrm{VI})$ is not reduced abiotically or biotically during the post-acetate amendment time period, or otherwise scavenged by incorporation into a newly formed phase such as calcite. While such mechanisms have been proposed (Hyun et al., 2012; N'Guessan et al., 2008), the process of filling of vacated sorption sites is consistent with reactive transport modeling described below, and provides the simplest explanation of the differences in $\mathrm{U}(\mathrm{VI})$ rebound under bicarbonate-acetate and acetate-only conditions.

3.6 Speciation of Aqueous $U$. Figure 6 compares the calculated $\mathrm{U}(\mathrm{VI})$ speciation in groundwater over the duration of the experiment in wells CD01 (acetate-only) and CD14 (bicarbonate-acetate). The dissolved U(VI) speciation was dominated by the same five complexes in both cases, with uncharged calcium-uranyl tricarbonato species $\left(\mathrm{Ca}_{2}\right) \mathrm{UO}_{2}\left(\mathrm{CO}_{3}\right)_{3}{ }^{0}$ making up $\sim 97 \%$ of the dissolved $\mathrm{U}$, followed by $\mathrm{CaUO}_{2}\left(\mathrm{CO}_{3}\right)_{3}{ }^{2-}$, $\mathrm{MgUO}_{2}\left(\mathrm{CO}_{3}\right)_{3}{ }^{2-}$, and $\mathrm{UO}_{2}\left(\mathrm{CO}_{3}\right)_{3}{ }^{4-}$. Note that these species all contain 3 carbonate ligands, so we refer to the sum of these four species as the uranyl-tricarbonato species, and the group of all other dissolved $\mathrm{U}(\mathrm{VI})$ species as the non-tricarbonato species. The $\mathrm{UO}_{2}\left(\mathrm{CO}_{3}\right)_{2}{ }^{2-}$ species has the fifth highest concentrations of dissolved $\mathrm{U}(\mathrm{VI})$ in both wells; its concentration was more than 3 orders of magnitude lower than the uncharged, calcium-uranyl tricarbonato species, but was about an order of magnitude higher under acetate-only conditions (CD01) than under bicarbonate-acetate conditions (CD14).

The concentrations of dissolved U(VI) in wells CD01 and CD14 were slightly different at the beginning and varied over the duration of the experiment. In well CD01 (acetateonly), the initial concentration was $0.75 \mu \mathrm{M}$, and $0.051 \%$ was calculated to be present as non-tricarbonato species. For CD14 (acetate-bicarbonate), the values were $0.66 \mu \mathrm{M}$ and $0.064 \%$. Figure 7 shows the ratio of the relative fraction of non-tricarbonato species in well CD14 (bicarbonate-acetate) to that in well CD01 (acetate-only) over the course of the experiment. The non-tricarbonato ratio is slightly greater than 1 at the beginning of the experiment, but then the ratio decreases rapidly to 0.25 during the bicarbonate and acetate additions to the groundwater (Fig. 7), as the increased bicarbonate concentration causes a greater proportion of dissolved $\mathrm{U}(\mathrm{VI})$ to be present as uranyl-tricarbonato species in well CD14. Later in the experiment (>40 days), the water chemistry at CD14 changes significantly as the bicarbonate plume is transported away and the nontricarbonato ratio for CD14:CD01 is again greater than 1 for a period of time.

As shown by Ulrich et al. (2011), the kinetics of uranium bioreduction are highly sensitive to $\mathrm{U}(\mathrm{VI})$ aqueous speciation, and thus depend significantly on $\mathrm{pH}$ and calcium and bicarbonate concentrations. The greater proportion of uranyl-tricarbonato species present under bicarbonate-amended conditions is therefore expected. However, $\Delta \mathrm{U}(\mathrm{VI})_{\mathrm{obs}}$ condt under bicarbonate-acetate and acetate-only conditions were still indistinguishable in spite of the laboratory observation that Ca-uranyl-tricarbonato species in particular are 
bioreduced at slower rates than non-tricarbonato species (Dong and Brooks, 2006; Stewart et al., 2007).

3.7 Microbiology. Relative changes in Plot C microbiology with time are shown in Figure 8 , and provide more extensive data than the amplification microarray data reported previously for this experiment (Chandler et al. 2013). Relative to the CU01 background (i.e., unimpacted by acetate or bicarbonate) signatures, the bloom of metal-reducing bacteria in all wells was dominated by Geobacter and Pelobacter 16S rRNA gene signatures, as expected. The transition from iron to sulfate reduction was accompanied by a decline in planktonic metal-reducers and an increase in Desulfotomaculum and Clostridium (data not shown, see doi:10.1594/PANGAEA.830272). The relative increase in Desulfotomaculum and Clostridium signatures is interesting in light of recent data indicating that some Desulfotomaculum and Clostridium species are capable of U(VI) reduction under fermentative conditions, even as spores (Bernier-Latmani et al., 2010; Junier et al., 2011; Junier et al., 2009). Discernable differences among the composition of microbial communities were not evident between acetate-only and bicarbonate-acetate amendments.

16S rRNA clone libraries constructed from groundwater samples collected from wells CD04 and CD14 on 9/16/2010 (Day 31) were collected as part of another microbiological study of the Super 8 experiment but provide results that are consistent with the hybridization microarray results (Fig. 9, upper panel). As expected for the acetate-only well CD04 ( 1.5 m downgradient from CD01), a large fraction $(\sim 75 \%)$ of the community belongs to the Deltaproteobacteria (Geobacter, sp. mainly, some Desulfobacteraceae). CD14 is also enriched in Betaproteobacteria, Gammaproteobacteria, and, notably, fermenters, including microorganisms from candidate division OD1 (Wrighton et al, 2012). The variability between the proportion of Deltaproteobacteria between the two wells is within the range of that observed previously (e.g., Anderson et al., 2003).

Microbial community data from a more extensive time series (13 samples from in situ sediment columns) representing the acetate-only treatment have been analyzed in a manner similar to data reported on earlier Rifle experiments (Handley et al., 2013; Handley et al., 2014; Handley et al., 2012; Wrighton et al., 2012). In brief, results indicate a community structure that is analogous to the groundwater communities in CD14 and CD04 at a similar time point in the experiment (Fig. 9, lower panel), with the exception that bacteria belonging to the Bacteriodetes phylum are more prevalent in the sediment (namely unclassified Sphingobacteria, Flavobacteria and Bacteroidetes). As in the groundwater acetate-bicarbonate CD14 community, Deltaproteobacteria and Betaproteobacteria dominate in near equal proportions within the sediment and are clearly enriched relative to un-amended background sediment and groundwater. Overall results indicate a similar microbiological response was achieved during both acetate and acetate-bicarbonate experiments that also reflects results obtained during previous experiments (Anderson et al., 2003; Handley et al., 2012). Recognizing that 16S rRNA data on groundwater and sediments may not be exactly comparable to the hybridization microarray data, the $16 \mathrm{~S}$ rRNA data indicate that the microbial community during biostimulation was typical for Rifle in situ acetate amendment experiments. They are 
broadly consistent with the hybridization microarray results and thus provide independent corroboration of the microarray data.

3.8 Reactive Transport Modeling and U(VI) Reduction Rates. Observed and simulated aqueous U(VI) concentrations were well correlated for most of the 27 monitoring locations over a 70-day simulation period (Fig. S-3). Simulated aqueous U(VI) concentrations under bicarbonate-only conditions (CU03 and CU04) rapidly increased from $0.5 \mu \mathrm{M}$ to $\sim 1.5 \mu \mathrm{M}$ before a continuous decline. In the three rows of monitoring wells directly downgradient from the bicarbonate injection (CD11/12, CD13/14/15, and CD16/17), the peak concentration of the simulated aqueous U(VI) pulse progressively increased to $\sim 2.0 \mu \mathrm{M}$. This peak reflects the accumulation of desorbed U(VI) as more of the aquifer sediments were impacted by the bicarbonate front moving through the aquifer. The occurrence of the simulated peak before the observed peaks in U(VI) concentration are related to the use of an equilibrium model, and the attenuation could be better described with a kinetic model for U(VI) desorption (Fox et al., 2012). The duration of this elevated $\mathrm{U}(\mathrm{VI})$ pulse is limited by both depletion of adsorbed U(VI) and U(VI) bioreduction that begins with injection of acetate on day 8 .

Figure 10 shows simulated U(VI) reduction rates at all monitoring locations over the 70day simulation period. These rates are normalized to U(VI) concentration to account for the expected increase in U(VI) reduction rate with increasing U(VI) concentration based on Monod kinetics or the in silico model for iron-reducing bacteria (FeRB) used for this plot (Fang et al., 2012). Figures S-4, S-6, S-7, and S-8 show absolute rates and rates normalized to FeRB biomass using the method of Bao et al. (2014). Per the modeling schema, the simulated rates are exclusively the result of $U(V I)$ bioreduction and are derived from the time-dependent change in amount of $U(V I)$ reduced (i.e., slope of graphs in Fig. S-2), providing the local reaction rate for $\mathrm{U}(\mathrm{VI})$ reduction.

The highest simulated U(VI)-bioreduction rates (normalized to U(VI) concentration, Fig. 10) occur in the bicarbonate-acetate part of the experiment at day 37 to day 55, depending on well location. At wells CD10, CD11, CD12, CD13, CD14, and CD16, peak simulated reduction rates range from 0.30 to $0.35 \mathrm{~mol} \mathrm{~L}^{-1} \mathrm{~d}^{-1}$ mol ${ }_{\mathrm{U}(\mathrm{VI})}{ }^{-1} \mathrm{~L}^{-1}$ (or $\mathrm{d}^{-1}$ ), with a mean value of $0.33(1 \sigma=0.014, \mathrm{n}=6)$. Locations unimpacted by the bicarbonate injection (e.g., CD01) have simulated rates of $\sim 0.06$ to $0.1 \mathrm{~mol} \mathrm{~L}^{-1} \mathrm{~d}^{-1} \mathrm{~mol}_{\mathrm{U}(\mathrm{VI})}{ }^{-1} \mathrm{~L}^{-1}$ at the times of peak reduction rate in the wells above with a mean value $=0.087(1 \sigma=0.015, \mathrm{n}=6)$. Thus peak simulated rates in bicarbonate-acetate wells are $\sim 3.8$ times higher than in the acetate-only wells.

The model output estimates the U(VI) bioreduction rate during the experiment for either bicarbonate-acetate or acetate-only wells. Results clearly show that the estimated bioreduction rates for the acetate-bicarbonate treatment (well CD11) are higher than those for the acetate-only treatment (well CD01) 7 to $\sim 25$ days from the start of acetate amendment for both the un-normalized U(VI) bioreduction rate and for the U(VI) reduction rate normalized to biomass (Fig. S-6). For the U(VI) bioreduction rate normalized to U(VI) concentration (Fig. 10 and Fig. S-5), the estimated rate for the bicarbonate-acetate treatment exceeds rates for the acetate-only treatment from $\sim 7$ to $\sim 62$ 
days from the start of the experiment. The rates diverge from $\sim 13$ to $\sim 35$ days, with increasingly greater rates for the bicarbonate-acetate treatment while rates in CD01 (for example) remain nearly constant. This is the appropriate comparative time period during which acetate levels are similar on both sides of the experiment. As expected, the time of peak estimated U(VI) reduction rates shift to later times in further down-gradient wells.

The model does show significant simulated reduction rates for wells CU03 and CU04 that are $\sim 1 \mathrm{~m}$ upgradient from the line of acetate injection wells. Non-zero U(VI) reduction rates are expected in these wells due to transport of acetate away from injection wells during cycling of cross-well mixing. Peak rates of $1 / 3$ or $1 / 2$ of the peak rates in nearby down-gradient wells are likely overestimated given the low measured acetate concentrations in these wells.

\section{Discussion}

$4.1 U(V I)$ desorption and changes in $U$ aqueous complexes. The impact of U(VI) desorption on $\mathrm{U}(\mathrm{VI})$ aqueous concentrations is clearly demonstrated by this experiment. Results from monitoring wells downgradient from the bicarbonate injection (e.g., CU03) suggest that U(VI) desorption began to deplete the available pool of sorbed U(VI) based on the declining U(VI) concentrations, while bicarbonate concentrations remained at or near their peak concentrations. The implication of this observation is that near-complete desorption of labile U(VI) is feasible over reasonably short time frames (days to weeks) and that it might be practical to use desorption as a remedial technology either as a standalone U(VI) flushing process or in combination with bioreduction to enhance bioavailability of U(VI). Results from the experiment confirm earlier work (Phillips et al., 1995; Williams et al., 2011) that shows no apparent inhibition of the reduction of $\mathrm{U}(\mathrm{VI})$ even when calcium-uranyl tricarbonato complexes dominate aqueous species.

However, the net effect of bicarbonate addition to the system is complex, increasing total dissolved U(VI) but also decreasing the proportion of more readily bioavailable nontricarbonato species. Note that the decrease in U(VI) concentration begins even when DIC and $\delta \mathrm{D}$ are still rising, indicating that microbial reduction is outpacing U(VI) desorption on the bicarbonate-acetate side of the experiment (e.g. well CD14). The net effect on enzymatic $\mathrm{U}(\mathrm{VI})$ reduction is thus also complex, with the simulated absolute rate of reduction faster in CD14 than at CD01 (for days 7-23, Fig. S-4), partly related to the greater total dissolved U(VI) concentration. The simulated rate of reduction per mole of $U(V I)$ is faster on the bicarbonate-acetate side for a longer duration (days 12-62). The proportion of uranyl-tricarbonato species during days 10-40 on the bicarbonate side of the experiment likely plays a limited role in the U(VI) reduction rates (Fig. 7 cf. Fig. 10 CD01 and CD14), but the mechanistic interaction between $\mathrm{U}$ speciation and microbial reduction of U(VI) is still poorly understood. Given the increase abundance of uranyltricarbonato species under conditions of bicarbonate-acetate (Ulrich et al. 2011 and Figure 7), it would be expected that there would be lower $\Delta \mathrm{U}(\mathrm{VI})_{\text {obs conc }} / \mathrm{t}$ on the acetatebicarbonate amended side of the experiment. This difference might be expected to be significant enough to show up directly in U(VI) concentrations as function of time. As 
this is not the case, it suggests that 1) the model assumption that U(VI) aqueous species re-equilibrate, diffuse, or advect rapidly such that there is no decrease in the $\Delta \mathrm{U}(\mathrm{VI})_{\text {obs }}$ cond $/ \mathrm{t}$ with bicarbonate amendment is correct, or 2) under Rifle field conditions the in situ biostimulated microbial community is not sufficiently sensitive to U(VI) aqueous speciation to affect the rates of bioreduction (Ortiz-Bernad et al., 2004a).

\subsection{Impacts of Bicarbonate on the Microbial Community and U(VI) bioreduction rates.}

Univariate and multivariate statistical analysis of the microarray data show no consistent differences in the microbial community structure between the bicarbonate-acetate and the acetate-only treatments (Fig. S-9). The analysis indicates that total biomass is not correlated with TIC, acetate concentration and metal reducers but positively correlated with sulfate reducers and fermenters, consistent with the microbial succession during the field experiments at Rifle (i.e., biomass increases with time or the degree of stimulation). This analysis is consistent with the temporal differences in microbial biomass (total signal to noise ratio, SNR) in bicarbonate-impacted wells in Figure 8. In addition, simulated $\mathrm{U}(\mathrm{VI})$ reduction rates normalized to $\mathrm{U}(\mathrm{VI})$ concentration are higher for the bicarbonate-acetate treatment than for the acetate-only treatment. These results suggest that although the acetate-bicarbonate treated microbial community is compositionally indistinguishable from the acetate treated community, the former is more effective at $\mathrm{U}(\mathrm{VI})$ reduction, irrespective of total planktonic biomass (Fig S-6), or concurrent reduction of bioavailable oxidized iron (Bao et al. 2014). Heterogeneity in bioavailable $\mathrm{Fe}$ (III) could partially account for differences in Fe-reducers across the experimental domain, but these difference do not translate into modeled differences in U(VI) reduction rate. Since there are no consistent differences in community structure, or biomass between the bicarbonate-acetate and acetate-only treatments, the difference in U(VI) reduction rate must be related to the difference in bicarbonate and its impact on the intrinsic $\mathrm{U}(\mathrm{VI})$ reduction rate of that part of the microbial community responsible for $\mathrm{U}(\mathrm{VI})$ reduction, most likely the metal reducers (Figure 8).

Chandler et al. (2013) suggested that dissolved $\mathrm{CO}_{2}$ may enhance the reverse tricarboxylic acid cycle of U-respiring organisms, leading to increased rates of U(VI) reduction per cell. Oxyanions, sulfate, silicate, and phosphate have been shown to favor microbial precipitation of monomeric U(IV) by increasing bacterial extracellular polymeric substances (EPS) and bacterial viability (Stylo et al., 2013), providing further evidence that the oxyanion bicarbonate may also impact U(IV) species and reduction rates. On the other hand, the oxyanion bicarbonate favors formation of uraninite $\left(\mathrm{UO}_{2}\right)$ and suppresses the production of monomeric U(IV) (Bernier-Latmani et al., 2010). The general importance of bicarbonate to microbial redox processes is also supported by its effect on microbial products of Fe(II) oxidation, in which the formation of goethite $(\alpha-$ $\mathrm{FeOOH})$ at the expense lepidocrocite $(\gamma-\mathrm{FeOOH})$ was favored under conditions of high increased bicarbonate and humic acid (Larese-Casanova et al., 2010). However, bicarbonate does not seem to have a strong impact without the presence of microbes. For example, abiotic reduction of U(VI) by FeS was not impacted by the presence or absence of bicarbonate (Gallegos et al., 2013), again supporting the concept that bicarbonate increases $\mathrm{U}(\mathrm{VI})$ reduction rates by impacting the metabolism of the subsurface microbial community. 
The attached microbial community may also play a role in governing U(VI) reduction rates under Fe-reducing conditions (Bargar et al. 2013), which would not be fully accounted for by sampling the planktonic community in groundwater in this study. However, attached and planktonic Geobacter sp. are similar during acetate biostimulation (Holmes et al., 2007a), although other important differences in community membership may exist (e.g. Fig. 9). Based on currently available data, it seems unlikely that the unsampled, attached population of Fe-reducers accounts for the difference in U(VI) reduction rate on the two sides the Super 8 experimental plot. Since the Holmes et al. (2007a) data were collected only under conditions of acetate stimulation, the possibility that attached versus unattached Fe-reducer populations are different under conditions of bicarbonate-acetate cannot be entirely ruled out. In addition, changes in DNA signatures over time do not necessarily correlate with metal-reducing activity or rates in situ. For example, analysis of samples collected from CD04 during the Super 8 experiment in conjunction with ex situ column experiments demonstrate that $r p s$ gene expression correlates better with the rate of Geobacter sp. growth and metabolism than changes in cell abundance (Holmes et al., 2013a). U(VI) is a trace electron acceptor at Rifle compared to the major electron acceptors that are available for anaerobic respiration (e.g. $\mathrm{Fe}(\mathrm{III})$ ), and as noted above, a wide range of organisms can reduce $\mathrm{U}(\mathrm{VI})$, so relatively low-abundance of any U(VI)-reducing cells could account for the difference in U(VI) reduction rate.

Putative fermenters are present in most wells (Fig. 8), commonly increasing as the experiment progressed. Part of the taxonomically inferred fermentative community includes organisms from the OD1 candidate division (Wrighton et al., 2012). Recent research indicates that the fermentative community is important in carbon, sulfur, and nitrogen cycling under biostimulated conditions with implication for utilization of natural dissolved and detrital organic carbon in sediments (Wrighton et al., 2014). Some of the organisms inferred to be obligate fermenters described in these studies also cycle hydrogen which may drive $\mathrm{U}(\mathrm{VI})$ reduction and could account for some of the U(VI) reduction in the later stages of the experiment (Bargar et al., 2013; Bernier-Latmani et al., 2010). In addition, abiotic reduction of U(VI) by sorbed Fe(II) or by FeS could make a small contribution to the total observed U(VI) reduction under these experimental conditions (Fox et al., 2013; Hyun et al., 2012).

\subsection{Complexity of processes Governing U(VI) Concentrations During Bioreduction. In} the case of both iron and uranium, it is particularly difficult to quantitatively discern the individual contributions of processes governing their concentrations from measured concentrations alone. This is because both elements have complex aqueous and solid species that are directly involved in aqueous and surface complexation, microbially mediated terminal electron accepting processes (TEAPs), and mineral reactions, which are sensitive to geochemical parameters such as $\mathrm{pH}, \mathrm{Eh}, \mathrm{Fe}(\mathrm{III})$, and alkalinity which are in turn controlled by reactions involving other elements. For example, minor increases in bicarbonate as a byproduct of microbial respiration during electron donor field experiments (Williams et al., 2011) not only promotes U(VI) desorption, but also may exert a positive feedback for enhanced microbial reduction of $\mathrm{U}(\mathrm{VI})$, albeit at a lower rate than when high concentrations of bicarbonate are amended to the subsurface. 
Another example of the complexity of $U$ biogeochemistry is the structure and bonding of $\mathrm{U}(\mathrm{IV})$ products of bioreduction. The simulated U(VI) bioreduction rates are the most readily available estimate because of the practical difficulty of obtaining subsurface sediment samples and the challenge of simultaneously measuring sorbed U(IV) and the concentration of monomeric U(IV) and uraninite in bioreduced sediments (Alessi et al., 2012; Stoliker et al., 2013). Moreover, X-ray spectroscopy has been very successful at identifying $U$ redox status and bonding of $U$ phases, but has not yet been able to quantify $\mathrm{U}(\mathrm{IV})$ at typical concentrations in a sediment matrix (total $\mathrm{U}$ in Rifle sediments is 0.4 to $0.9 \mathrm{mg} / \mathrm{kg}$, see Bargar et al., 2013 Table 1). In-well columns in which the concentration of U(VI) was increased by amendment with $20 \mu \mathrm{M}$ uranyl do enable both reliable bicarbonate extractions and synchrotron X-ray spectroscopy (Alessi et al., 2014; Alessi et al., 2012; Bargar et al., 2013; Cerrato et al., 2013). In these studies, limited sampling (e.g. 3 time points over 102 days, Alessi et al, 2014) precludes calculation of rates comparable to the simulated rates reported here. Sediments from the in-well columns do show the prevalence of U(IV) (90\%), two thirds of which is non-crystalline U(IV) (Alessi et al., 2014). Broadly the thermodynamics of uraninite and non-crystalline U(VI) formation from soluble U(VI) are likely similar since both involve the same electron transitions, supporting the model use of uraninite formation constants for this study. However, the reactivity of non-crystalline $\mathrm{U}(\mathrm{VI})$ is clearly greater than that of uraninite (Cerrato et al., 2013). Future reactive models will be more useful for assessing the post-bioreduction behavior of $\mathrm{U}(\mathrm{IV})$ if they incorporate the differences in reactivity between uraninite and non-crystalline U(IV).

$\mathrm{Fe}(\mathrm{III})$ concentrations in aquifer sediments provide another example of complex relationships among geochemical reactions. In the reactive transport model described in this paper, neither physical nor geochemical heterogeneity is required in the model for it to match observations, suggesting that the biogeochemical process behaviors dominate any impacts of heterogeneity in this experiment. Modeling of the same experimental data by Bao et al. (2014) is based on a fundamentally different view of the role of geochemical subsurface heterogeneity in Fe(III). In the Bao et al. (2014) model, an inverse relationship between permeability and the concentration of bioavailable oxidized $\mathrm{Fe}$ is posited for the subsurface aquifer hosting the Super 8 experiment. The model simulation of Bao et al. did show higher bioreduction rates in the bicarbonate injection zone, similar to the simulation results presented here. The Bao et al. rates are, on average, similar, but their simulations show significant heterogeneity in bioreduction rates, which derives from the variable content of $\mathrm{Fe}$ (III)-containing minerals in the model domain inferred from the correlation between Fe(III) mineral, clay content, and the associated hydraulic conductivity based on the borehole flow meter measurement. Another key difference between the two models is that the fully 3-D model described in this paper accounts for changes in the saturated thickness and gradient magnitude, whereas the 2-D Bao et al. model uses a constant pressure gradient and saturated thickness. The differences in the two models offers opportunity for detailed comparison in future research that would make it possible to determine if biogeochemical heterogeneity, including reduced phases (Bargar et al., 2013; Borch et al., 2012; Zhao et al., 2013), or the fundamental capabilities of the microbial community are more important in 
determining outcomes of U(VI) bioreduction at Rifle. Results of such a determination would have broad implications for subsurface biogeochemical processes globally.

\section{Conclusions}

The field experiment described here compares, for the first time, bicarbonate-promoted uranium desorption and acetate amendment within the same subsurface experimental plot. Enzymatic U(VI)-reduction was not inhibited by the addition of bicarbonate and the associated increase in the predominance of Ca-uranyl-carbonato aqueous complexes. Instead, the simulated peak rate of U(VI)-reduction during acetate-bicarbonate amendment was $\sim 3.8$ times higher than under acetate-only conditions. Lack of statistically significant differences between the microbial populations under conditions of elevated versus background concentrations of bicarbonate suggest that metabolic processes associated with increased bicarbonate concentrations may be responsible for the increased rate of bioreduction of $\mathrm{U}(\mathrm{VI})$; however, additional research is needed to elucidate the mechanisms involved. Overall, the experiment indicates that, under the conditions studied, the efficacy of bioremediation of uranium in aquifers can be enhanced by bicarbonate amendment, and that natural cycling of the redox status of uranium in the subsurface may be more sensitive to bicarbonate concentrations than previously thought.

\section{Acknowledgements}

This work was supported by the Director, Office of Science, Biological and Environmental Research, Subsurface Biogeochemistry Program of the U.S. Department of Energy under Contract No. DE-AC02-05CH11231. We thank the entire Rifle, Colorado Integrated Field Challenge (IFRC) team for their contributions to the Super 8 Experiment, including the U.S. Department of Energy, Grand Junction Office for their excellent field support. We also thank Jason Greenwood for assistance with Figure 1, Roelof Versteeg for help with uploading data to Pangaea, and anonymous Reviewer \#2 for extensive, detailed and very helpful comments that significantly improved the manuscript.

\section{References}

Alessi, D.S., Pacheco, J.S.L., Janot, N., Suvorova, E.I., Cerrato, J.M., Giammar, D.E., Davis, J.A., Fox, P.M., Williams, K.H., Long, P.E., Handley, K.M., Bernier-Latmani, R., Bargar, J., 2014. Speciation and reactivity of uranium products formed during in situ bioremediation in a shallow alluvial aquifer. Environ. Sci. Technol. In press. $10.1021 / \mathrm{es} 502701 \mathrm{u}$

Alessi, D.S., Uster, B., Veeramani, H., Suvorova, E.I., Lezama-Pacheco, J.S., Stubbs, J.E., Bargar, J.R., Bernier-Latmani, R., 2012. Quantitative Separation of Monomeric U(IV) from UO2 in Products of U(VI) Reduction. Environ Sci Technol 46, 6150-6157. Doi 10.1021/Es204123z

Amann, R.I., Binder, B.J., Olson, R.J., Chisholm, S.W., Devereux, R., Stahl, D.A., 1990. Combination of 16s Ribosomal-Rna-Targeted Oligonucleotide Probes with FlowCytometry for Analyzing Mixed Microbial-Populations. Appl Environ Microb 56, 19191925. 
Andersen, G.L., He, Z., DeSantis, T.Z., Brodie, E.L., Zhou, J., 2010. The use of microarrays in microbial ecology. Environ Mol Microbiol, 87-109.

Anderson, R.T., Vrionis, H.A., Ortiz-Bernad, I., Resch, C.T., Long, P.E., Dayvault, R., Karp, K., Marutzky, S., Metzler, D.R., Peacock, A., White, D.C., Lowe, M., Lovley, D.R., 2003. Stimulating the in situ activity of Geobacter species to remove uranium from the groundwater of a uranium-contaminated aquifer. Appl Environ Microb 69, 5884-5891. Doi 10.1128/Aem.69.10.5884-5891.2003

Bao, C., Wu, H., Li, L., Williams, K.H., Long, P., Newcomer, D., Steefel, C., 2014. Uranium Bioreduction Rates Across Scales: Biogeochemical "Hot Moments" and "Hot Spots" During a Field Biostimulation Experiment at Rifle, Colorado. Environ. Sci. Technol. In Review.

Bargar, J.R., Williams, K.H., Campbell, K.M., Long, P.E., Stubbs, J.E., Suvorova, E.I., LezamaPacheco, J.S., Alessi, D.S., Stylo, M., Webb, S.M., Davis, J.A., Giammar, D.E., Blue, L.Y., Bernier-Latmani, R., 2013. Uranium redox transition pathways in acetate-amended sediments. P Natl Acad Sci USA 110, 4506-4511. Doi 10.1073/Pnas.1219198110

Berman, E.S.F., Gupta, M., Gabrielli, C., Garland, T., McDonnell, J.J., 2009. High-frequency field-deployable isotope analyzer for hydrological applications. Water Resour Res 45, W10201. 10.1029/2009wr008265

Bernier-Latmani, R., Veeramani, H., Vecchia, E.D., Junier, P., Lezama-Pacheco, J.S., Suvorova, E.I., Sharp, J.O., Wigginton, N.S., Bargar, J.R., 2010. Non-uraninite Products of Microbial U(VI) Reduction. Environ Sci Technol 44, 9456-9462. Doi 10.1021/Es101675a

Bopp, C.J.I., Lundstrom, C.C., Johnson, T.M., Sanford, R.A., Long, P.E., Williams, K.H., 2010. Uranium 238U/235U Isotope Ratios as Indicators of Reduction: Results from an in situ Biostimulation Experiment at Rifle, Colorado, U.S.A. Environ. Sci. Technol. 44, 59275933. 10.1021/es100643v

Borch, T., Roche, N., Johnson, T.E., 2012. Determination of contaminant levels and remediation efficacy in groundwater at a former in situ recovery uranium mine. J. Environ. Monit. 14, 1814-1823. 10.1039/c2em30077j

Campbell, K.M., Davis, J., Bargar, J., Giammar, D., Bernier-Latmani, R., Kukkadapu, R., Williams, K., Veramani, H., Ulrich, K.-U., Stubbs, J., 2011. Composition, stability, and measurement of reduced uranium phases for groundwater bioremediation at Old Rifle, CO. Applied Geochemistry 26, S167-S169.

Cerrato, J.M., Ashner, M.N., Alessi, D.S., Lezama-Pacheco, J.S., Bernier-Latmani, R., Bargar, J.R., Giammar, D.E., 2013. Relative reactivity of biogenic and chemogenic uraninite and biogenic noncrystalline U(IV). Environ. Sci. Technol. 47, 9756-9763.

Chandler, D.P., Knickerbocker, C., Bryant, L., Golova, J., Wiles, C., Williams, K.H., Peacock, A.D., Long, P.E., 2013. Profiling In Situ Microbial Community Structure with an Amplification Microarray. Appl Environ Microb 79, 799-807.

Chandler, D.P., Kukhtin, A., Mokhiber, R., Knickerbocker, C., Ogles, D., Rudy, G., Golova, J., Long, P.E., Peacock, A., 2010. Monitoring Microbial Community Structure and Dynamics during in situ U(VI) Bioremediation with a Field-Portable Microarray Analysis System. Environ. Sci. Technol. 44, 5516-5522. 10.1021/es1006498

Curtis, G.P., Fox, P., Kohler, M., Davis, J.A., 2004. Comparison of in situ uranium $<\mathrm{i}>\mathrm{K}</ \mathrm{i}><$ sub $>\mathrm{D}</$ sub $>$ values with a laboratory determined surface complexation model. Applied Geochemistry 19, 1643-1653.

Davis, J.A., Meece, D.E., Kohler, M., Curtis, G.P., 2004. Approaches to surface complexation modeling of uranium (VI) adsorption on aquifer sediments. Geochimica Et Cosmochimica Acta 68, 3621-3641.

Davis, J.A., Payne, T.E., Waite, T.D., 2002. Simulating the pH and pCO2 dependence of uranium (VI) adsorption by a weathered schist with surface complexationmodels, in: Zhang, P.-C., 
Brady, P.V. (Eds.), Geochemistry of Soil Radionuclides. SSSA Special Publication Number 59, Soil Science Society of America, Madison, WI, pp.61-86, pp. 61-86.

DOE, 1999. Final Site Observational Work Plan for the UMTRA Project Old Rifle Site. GJO-9988-TAR Rev 1. U.S. Department of Energy, Grand Junction Office, Grand Junction, Colorado.

DOE, 2001. Ground Water Compliance Actin Plan for the Old Rifle, Colorado, UMTRA Project Site, in: Energy, U.S.D.o. (Ed.). U.S. Government, Grand Junction, Colorado, p. 18.

Dong, W., Brooks, S.C., 2006. Determination of the formation constants of ternary complexes of uranyl and carbonate with alkaline earth metals $(\mathrm{Mg} 2+, \mathrm{Ca} 2+, \mathrm{Sr}+$, and $\mathrm{Ba} 2+)$ using anion exchange method. Environ Sci Technol 40, 4689-4695.

Dong, W.M., Brooks, S.C., 2008. Formation of aqueous MgUO2(CO3)(3)(2-) complex and uranium anion exchange mechanism onto an exchange resin. Environ Sci Technol 42, 1979-1983. Doi 10.1021/Es0711563

Druhan, J.L., Bill, M., Lim, H., Wu, C., Conrad, M.E., Williams, K.H., DePaolo, D.J., Brodie, E.L., 2014a. A large column analog experiment of stable isotope variations during reactive transport: II. Carbon mass balance, microbial community structure and predation. Geochimica Et Cosmochimica Acta 124, 394-409.

Druhan, J.L., Steefel, C.I., Conrad, M.E., DePaolo, D.J., 2014b. A large column analog experiment of stable isotope variations during reactive transport: I. A comprehensive model of sulfur cycling and $\delta<\sup >34</$ sup $>$ S fractionation. Geochimica Et Cosmochimica Acta 124, 366-393.

Fang, Y., Yabusaki, S., Morrison, S., Amonette, J.P., Long, P., 2009a. Multicomponent reactive transport modeling of uranium bioremediation field experiments. Geochim Cosmochim Acta 73, 6029-6051. doi:10.1016/j.gca.2009.07.019

Fang, Y., Yabusaki, S.B., Morrison, S.J., Amonette, J.P., Long, P.E., 2009b. Multicomponent reactive transport modeling of uranium bioremediation field experiments. Geochim Cosmochim Ac 73, 6029-6051.

Fang, Y.L., Wilkins, M.J., Yabusaki, S.B., Lipton, M.S., Long, P.E., 2012. Evaluation of a Genome-Scale In Silico Metabolic Model for Geobacter metallireducens by Using Proteomic Data from a Field Biostimulation Experiment. Appl Environ Microb 78, 87358742. Doi 10.1128/Aem.01795-12

Fox, P.M., Davis, J.A., Hay, M.B., Conrad, M.E., Campbell, K.M., Williams, K.H., Long, P.E., 2012. Rate-limited U(VI) desorption during a small-scale tracer test in a heterogeneous uranium-contaminated aquifer. Water Resour. Res. 48, W05512. 10.1029/2011WR011472

Fox, P.M., Davis, J.A., Kukkadapu, R., Singer, D.M., Bargar, J., Williams, K.H., 2013. Abiotic U (VI) Reduction by Sorbed Fe (II) on Natural Sediments. Geochimica Et Cosmochimica Acta 117, 266-282. http://dx.doi.org/10.1016/j.gca.2013.05.003

Gallegos, T.J., Fuller, C.C., Webb, S.M., Betterton, W., 2013. Uranium(VI) Interactions with Mackinawite in the Presence and Absence of Bicarbonate and Oxygen. Environ Sci Technol 47, 7357-7364. Doi 10.1021/Es400450z

Giloteaux, L., Holmes, D.E., Williams, K.H., Wrighton, K.C., Wilkins, M.J., Montgomery, A.P., Smith, J.A., Orellana, R., Thompson, C.A., Roper, T.J., Long, P.E., Lovley, D.R., 2013. Characterization and transcription of arsenic respiration and resistance genes during in situ uranium bioremediation. Isme Journal 7, 370-383. Doi 10.1038/Ismej.2012.109

Gorby, Y.A., Lovley, D.R., 1992. Enzymatic Uranium Precipitation. Environ Sci Technol 26, 205-207. Doi 10.1021/Es00025a026

Guillaumont, R., Fanghänel, T., Fuger, J., Grenthe, I., Neck, V., Palme, D.A., Rand, M.H., 2003. Update on the chemical thermodynamics of uranium, neptunium, plutonium, americium and technetium. Elsevier, Elsevier, Amsterdam. 
Handley, K.M., VerBerkmoes, N.C., Steefel, C.I., Williams, K.H., Sharon, I., Miller, C.S., Frischkorn, K.R., Chourey, K., Thomas, B.C., Shah, M.B., Long, P.E., Hettich, R.L., Banfield, J.F., 2013. Biostimulation induces syntrophic interactions that impact C, S and $\mathrm{N}$ cycling in a sediment microbial community. Isme Journal 7, 800-816. Doi 10.1038/Ismej.2012.148

Handley, K.M., Wrighton, K.C., Miller, C.S., Wilkins, M.J., Kantor, R.S., Thomas, B.C., Williams, K.H., Gilbert, J.A., Long, P.E., Banfield, J.F., 2014. Disturbed subsurface microbial communities follow equivalent trajectories despite different structural starting points. Environ Microbiol 10.1111/1462-2920.12467. 10.1111/1462-2920.12467

Handley, K.M., Wrighton, K.C., Piceno, Y.M., Andersen, G.L., DeSantis, T.Z., Williams, K.H., Wilkins Mj, M.J., Lucie N'Guessan, A., Peacock, A., Bargar, J., Long, P.E., Banfield, J.F., 2012. High-Density PhyloChip profiling of stimulated aquifer microbial communities reveals a complex response to acetate amendment. FEMS Microbiology Ecology 81, 188-204. 10.1111/j.1574-6941.2012.01363.x

Herbelin, A.L., Westall, J.C., 1999. FITEQL 4.0: a Computer Program for Determination of Chemical Equilibrium Constants from Experimental Data. Oregon State University Report 99-01, Corvallis, Oregon.

Holmes, D.E., Giloteaux, L., Barlett, M., Chavan, M.A., Smith, J.A., Williams, K.H., Wilkins, M., Long, P., Lovley, D.R., 2013a. Molecular Analysis of the In Situ Growth Rates of Subsurface Geobacter Species. Appl Environ Microb 79, 1646-1653.

10.1128/aem.03263-12

Holmes, D.E., Giloteaux, L., Williams, K.H., Wrighton, K.C., Wilkins, M.J., Thompson, C.A., Roper, T.J., Long, P.E., Lovley, D.R., 2013b. Enrichment of specific protozoan populations during in situ bioremediation of uranium-contaminated groundwater. ISME J 10.1038/ismej.2013.20. 10.1038/ismej.2013.20

Holmes, D.E., O'Neil, R.A., Vrionis, H.A., N'Guessan, L.A., Ortiz-Bernad, I., Larrahondo, M.J., Adams, L.A., Ward, J.A., Nicoll, J.S., Nevin, K.P., Chavan, M.A., Johnson, J.P., Long, P.E., Lovley, D.R., 2007a. Subsurface clade of Geobacteraceae that predominates in a diversity of Fe(III)-reducing subsurface environments. Isme Journal 1, 663-677. Doi 10.1038/Ismej.2007.85

Holmes, D.E., O’Neil, R.A., Vrionis, H.A., N'Guessan, L.A., Ortiz-Bernad, I., Larrahando, M.J., Adams, L.A., Ward, J.E., Nicoll, J.S., Nevin, K.P., Chavan, M.A., Johnson, J.P., Long, P.E., Lovley, D.R., 2007b. Subsurface clade of Geobacteraceae that predominates in a diversity of $\mathrm{Fe}$ (III)-reducing subsurface environments. Isme J 1, 663-677.

Hwang, C.C., Wu, W.M., Gentry, T.J., Carley, J., Corbin, G.A., Carroll, S.L., Watson, D.B., Jardine, P.M., Zhou, J.Z., Criddle, C.S., Fields, M.W., 2009. Bacterial community succession during in situ uranium bioremediation: spatial similarities along controlled flow paths. Isme Journal 3, 47-64. Doi 10.1038/Ismej.2008.77

Hyun, S.P., Davis, J.A., Sun, K., Hayes, K.F., 2012. Uranium (VI) reduction by iron (II) monosulfide mackinawite. Environ Sci Technol 46, 3369-3376.

Hyun, S.P., Fox, P.M., Davis, J.A., Campbell, K.M., Hayes, K.F., Long, P.E., 2009. Surface complexation modeling of $U$ (VI) adsorption by aquifer sediments from a former mill tailings site at Rifle, Colorado. Environ Sci Technol 43, 9368-9373.

Junier, P., Dalla Vecchia, E., Bernier-Latmani, R., 2011. The Response of Desulfotomaculum reducens MI-1 to U(VI) Exposure: A Transcriptomic Study. Geomicrobiology Journal 28, 483-496. Doi 10.1080/01490451.2010.512031

Junier, P., Frutschi, M., Wigginton, N.S., Schofield, E.J., Bargar, J.R., Bernier-Latmani, R., 2009. Metal reduction by spores of Desulfotomaculum reducens. Environ Microbiol 11, 30073017. Doi 10.1111/J.1462-2920.2009.02003.X 
Kelly, S.D., Kemner, K.M., O'Loughlin, E.J., Wu, W.M., Criddle, C., Marsh, T.L., 2008. Monitoring uranium transformations. Geochimica Et Cosmochimica Acta 72, A462A462.

Komlos, J., Peacock, A., Kukkadapu, R.K., Jaffé, P.R., 2008. Long-Term Dynamics of Uranium Reduction/Reoxidation under Low Sulfate Conditions. Geochim Cosmochim Acta 72, 3603-3615.

Kostka, J.E., Green, S., Overholt, W., Wu, W.M., Criddle, C., Watson, D.B., Jardine, P., 2009. Subsurface microbial community structure correlates with uranium redox phases during in situ field manipulation in a contaminated aquifer. Geochimica Et Cosmochimica Acta 73, A688-A688.

Lane, D.J., Pace, B., Olsen, G.J., Stahl, D.A., Sogin, M.L., Pace, N.R., 1985. RapidDetermination of 16s Ribosomal-Rna Sequences for Phylogenetic Analyses. P Natl Acad Sci USA 82, 6955-6959. Doi 10.1073/Pnas.82.20.6955

Larese-Casanova, P., Haderlein, S.B., Kappler, A., 2010. Biomineralization of lepidocrocite and goethite by nitrate-reducing $\mathrm{Fe}$ (II)-oxidizing bacteria: effect of $\mathrm{pH}$, bicarbonate, phosphate, and humic acids. Geochimica Et Cosmochimica Acta 74, 3721-3734.

Li, L., Steefel, C.I., Kowalsky, M.B., Englert, A., Hubbard, S.S., 2010. Effects of physical and geochemical heterogeneities on mineral transformation and biomass accumulation during biostimulation experiments at Rifle, Colorado. J. Contam. Hydrol. 112, 45-63. 10.1016/j.jconhyd.2009.10.006

Li, L., Steefel, C.I., Williams, K.H., Wilkins, M.J., Hubbard, S.S., 2009. Mineral Transformation and Biomass Accumulation Associated With Uranium Bioremediation at Rifle, Colorado. Environ Sci Technol 43, 5429-5435.

Lovley, D.R., Phillips, E.J.P., Gorby, Y.A., Landa, E.R., 1991. Microbial Reduction of Uranium. Nature 350, 413-416. 10.1038/350413a0

Miller, C.S., Baker, B.J., Thomas, B.C., Singer, S.W., Banfield, J.F., 2011. EMIRGE: reconstruction of full-length ribosomal genes from microbial community short read sequencing data. Genome Biology 12, 12.

Miller, C.S., Handley, K.M., Wrighton, K.C., Frischkorn, K.R., Thomas, B.C., Banfield, J.F., 2013. Short-read assembly of full-length $16 \mathrm{~S}$ amplicons reveals bacterial diversity in subsurface sediments. PLoS ONE 8, e56018. 10.1371/journal.pone.0056018

Morrison, S.J., Spangler, R.R., Tripathi, V.S., 1995. Adsorption of Uranium(Vi) on Amorphous Ferric Oxyhydroxide at High-Concentrations of Dissolved Carbon(Iv) and Sulfur(Vi). J. Contam. Hydrol. 17, 333-346.

N'Guessan, A.L., Vrionis, H.A., Resch, C.T., Long, P.E., Lovley, D.R., 2008. Sustained removal of uranium from contaminated groundwater following stimulation of dissimilatory metal reduction. Environ Sci Technol 42, 2999-3004.

Newsome, L., Morris, K., Lloyd, J.R., 2014. The biogeochemistry and bioremediation of uranium and other priority radionuclides. Chemical Geology 363, 164-184.

Ortiz-Bernad, I., Anderson, R.T., Vrionis, H.A., Lovley, D.R., 2004a. Resistance of solid-phase $\mathrm{U}(\mathrm{VI})$ to microbial reduction during in situ bioremediation of uranium-contaminated groundwater. Appl Environ Microb 70, 7558-7560. Doi 10.1128/Aem.70.12.75587560.2004

Ortiz-Bernad, I., Anderson, R.T., Vrionis, H.A., Lovley, D.R., 2004b. Vanadium respiration by Geobacter metalireducens: Novel strategy for in situ removal of vanadium from groundwater. Appl Environ Microb 70, 3091-3095. Doi 10.1128/Aem.70.5.30913095.2004

Phillips, E.J.P., Landa, E.R., Lovley, D.R., 1995. Remediation of Uranium Contaminated Soils with Bicarbonate Extraction and Microbial U(Vi) Reduction. J Ind Microbiol 14, 203 207. Doi 10.1007/Bf01569928 
Shiel, A.E., Laubach, P.G., Johnson, T.M., Lundstrom, C.C., Long, P.E., Williams, K.H., 2013. No Measurable Changes in 238U/235U due to Desorption-Adsorption of U (VI) from Groundwater at the Rifle, Colorado, Integrated Field Research Challenge Site. Environ Sci Technol 47, 2535-2541.

Stewart, B.D., Neiss, J., Fendorf, S., 2007. Quantifying constraints imposed by calcium and iron on bacterial reduction of uranium (VI). Journal of environmental quality 36, 363-372.

Stoliker, D., Campbell, K., Fox, P.M., Singer, D., Kaviani, N., Carey, M., Peck, N.E., Bargar, J., Kent, D., Davis, J.A., 2013. Evaluating chemical extraction techniques for the determinationof uranium oxidation state in reduced aquifer sediments. Environ. Sci. Technol. 47, 9225-9232. 10.1021/es401450v

Stylo, M., Alessi, D.S., Shao, P.P., Lezama-Pacheco, J.S., Bargar, J.R., Bernier-Latmani, R., 2013. Biogeochemical controls on the product of microbial U (VI) reduction. Environ Sci Technol 47, 12351-12358.

Suzuki, Y., Kelly, S.D., Kemner, K.M., Banfield, J.F., 2005. Direct microbial reduction and subsequent preservation of uranium in natural near-surface sediment. Appl Environ Microb 71, 1790-1797.

Tang, G.P., Wu, W.M., Watson, D.B., Parker, J.C., Schadt, C.W., Shi, X.Q., Brooks, S.C., 2013. U(VI) Bioreduction with Emulsified Vegetable Oil as the Electron Donor - Microcosm Tests and Model Development. Environ Sci Technol 47, 3209-3217. Doi 10.1021/Es304641b

Ulrich, K.-U., Veeramani, H., Bernier-Latmani, R., Giammar, D.E., 2011. Speciation-dependent kinetics of uranium (VI) bioreduction. Geomicrobiology Journal 28, 396-409.

Williams, K.H., Long, P.E., Davis, J.A., Steefel, C.I., Wilkins, M.J., N'Guessan, A.L., Yang, L., Newcomer, D., Spane, F.A., Kerkhof, L.J., McGuinness, L., Dayvault, R., Lovely, D.R., 2011. Acetate availability and its influence on sustainable bioremediation of uraniumcontaminated groundwater. Geomicrobiology Journal 28, 519-539. 10.1080/01490451.2010.520074

Wrighton, K.C., Castelle, C.J., Wilkins, M.J., Hug, L.A., Sharon, I., Thomas, B.C., Handley, K.M., Mullin, S.W., Nicora, C.D., Singh, A., Lipton, M.S., Long, P.E., Williams, K.H., Banfield, J.F., 2014. Metabolic interdependencies between phylogenetically novel fermenters and respiratory organisms in an unconfined aquifer. ISME $\mathbf{J}$ 10.1038/ismej.2013.249. 10.1038/ismej.2013.249

Wrighton, K.C., Thomas, B.C., Sharon, I., Miller, C.S., Castelle, C.J., VerBerkmoes, N.C., Wilkins, M.J., Hettich, R.L., Lipton, M.S., WILLIAMS, K.H., LONG, P.E., Banfield, J.F., 2012. Fermentation, Hydrogen and Sulfur Metabolism in Multiple Uncultivated Bacterial Phyla. Science 337, 1661-1665 10.1126/science.1224041

Wu, Q., Sanford, R.A., Loffler, F.E., 2006. Uranium(VI) reduction by Anaeromyxobacter dehalogenans strain 2CP-C. Appl Environ Microb 72, 3608-3614. Doi 10.1128/Aem.72.5.3608-3614.2006

Wu, W.M., Carley, J., Green, S.J., Luo, J., Kelly, S.D., Van Nostrand, J., Lowe, K., Mehlhorn, T., Carroll, S., Boonchayanant, B., Lofller, F.E., Watson, D., Kemner, K.M., Zhou, J., Kitanidis, P.K., Kostka, J.E., Jardine, P.M., Criddle, C.S., 2010. Effects of nitrate on the stability of uranium in a bioreduced region of the subsurface. Environ Sci Technol 44, 5104-5111. 10.1021/es1000837

Xu, M., Wu, W.M., Wu, L., He, Z., Van Nostrand, J.D., Deng, Y., Luo, J., Carley, J., GinderVogel, M., Gentry, T.J., Gu, B., Watson, D., Jardine, P.M., Marsh, T.L., Tiedje, J.M., Hazen, T., Criddle, C.S., Zhou, J., 2010. Responses of microbial community functional structures to pilot-scale uranium in situ bioremediation. ISME J 4, 1060-1070. 10.1038/ismej.2010.31

Yabusaki, S.B., Fang, Y., Long, P.E., Resch, C.T., Peacock, A.D., Komlos, J., Jaffe, P.R., Morrison, S.J., Dayvault, R.D., White, D.C., Anderson, R.T., 2007. Uranium removal 
from groundwater via in situ biostimulation: Field-scale modeling of transport and biological processes. J. Contam. Hydrol. 93, 216-235. DOI

10.1016/j.jconhyd.2007.02.005

Yabusaki, S.B., Fang, Y., Williams, K.H., Murray, C.J., Ward, A.L., Dayvault, R.D., Waichler, S.R., Newcomer, D.R., Spane, F.A., Long, P.E., 2011. Variably saturated flow and multicomponent biogeochemical reactive transport modeling of a uranium bioremediation field experiment. Journal of Contaminant Hydrology 126, 271-290. 10.1016/j.jconhyd.2011.09.002

Yelton, A., Williams, K.H., Fournelle, J., Wrighton, K.C., Handley, K.M., Banfield, J.F., 2013. Vanadate and acetate biostimulation of contaminated sediments decreases diversity, selects for specific taxa and decreases aqueous V5+ concentration. Environ Sci Technol.

Zhao, J., Scheibe, T.D., Mahadevan, R., 2013. Model-based Analysis of Mixed Uranium (VI) Reduction by Biotic and Abiotic Pathways During in Situ Bioremediation. Chemical Geology 357, 215-222. 10.1016/j.chemgeo.2013.08.037 
Figure 1: Well layout for Plot C, site of the Super 8 field experiment. The Rifle field site location is provided in Williams et al., (2011). Inset shows the two tanks containing the separate injectates used in the experiment.

Figure 2. Concentration of selected geochemical constituents in well CU03 plotted versus time in days after 8/16/2010 (bicarbonate-only conditions). $\mathrm{NaHCO}_{3}$ injection period delineated by vertical bars. Relevant, maximum contaminant levels (MCL) and UMTRA standard concentrations are denoted by horizontal dashed lines with concentration values as shown.

Figure 3: Concentration of selected geochemical constituents in well CD01 plotted versus time in days after 8/16/2010 (acetate-only conditions). Acetate injection period delineated by vertical grey bars. MCL's and UMTRA standard are as shown in Figure 2.

Figure 4: Concentration selected geochemical constituents in well CD14 plotted versus time in days after 8/16/2010 (bicarbonate-acetate conditions). Acetate injection period delineated by vertical bars. MCL's and UMTRA standard are as shown in Figure 2.

Figure 5: Comparison of the behavior of aqueous U(VI), D and bromide tracers, acetate, and total inorganic carbon (TIC) in CU03 (A), CD01 (B) and CD14 (C). TIC concentrations result from the $\mathrm{NaHCO}_{3}$ injection (start and stops represented by dashed vertical lines). Starts and stops for acetate injection denoted by vertical grey bars (see Table 1). The inset in A. shows acetate with an expanded scale where acetate is above detection. MCL is as shown in Figure 2.

Figure 6. Plots of the total concentration of dissolved $U$ and calculated U(VI) aqueous species concentrations as a function of time in wells CD01 (A) and CD14 (B). Vertical lines are the same as in Figure 5. See "Materials and Methods" for details on calculations. Figure 7. Plot of the ratio of the calculated fractional contribution of non-tricarbonato species to total dissolved $\mathrm{U}$ in well CD14 versus well CD01 as a function of time. Vertical lines are the same as in Figure 5.

Figure 8. Spatial distribution and time variation of metal reducers, sulfate reducers and fermenters in selected wells based on microarray data. The $\mathrm{Y}$-axis scale on graphs is the signal to noise ratio, SNR, $\mathrm{X}$-axis scale is days since the start of the experiment. All graphs have the same scales (X-axis 0-70 days, Y-axis 0-500 SNR). Charts show stacked results for the three functional groups of bacteria. Wells CD11, CD14 and CD16 represent bicarbonate-acetate impacted wells as compared to CD02, CD05, and CD07 as acetate-only wells. Well CD-17 was missed by bicarbonate but was impacted by acetate. Day zero was 16 August 2010.

Figure 9. 16S rRNA gene clone library results (topmost chart) summarized to the class level for groundwater samples from wells CD-04 (acetate-only) and CD14 (bicarbonateacetate) on 16 September 2010. For comparison, reconstructed 16S rRNA gene results are given below for unamended sediment and sediment from 4 replicate flow-through columns collected from acetate-only wells on $12^{\text {th }}$ and $19^{\text {th }}$ of September 2010 (CD03, $\mathrm{CD} 01$ and $\mathrm{CD} 05)$. Reconstructed sequences used were present at $\geq 1 \%$ relative abundance.

Figure 10. Plots of the simulated U(VI) reduction rate normalized to U(VI) concentration as a function of time across the experimental domain. $\mathrm{Y}$-axis values are mol L $\mathrm{L}^{-1}$ $\operatorname{mol}_{\mathrm{U}(\mathrm{VI})}{ }^{-1} \mathrm{~L}^{-1}$ or $\mathrm{d}^{-1}$. Well numbers with a digit after a decimal point (e.g., CD-13.5) 
indicate wells with discrete sampling ports ranging from 1 to $3 \mathrm{~m}$ above the base of the modeling domain (elevation $1612.85 \mathrm{~m}$ above MSL). The ground surface is $6.5 \mathrm{~m}$ above the base of the modeling domain.

Table 1: Summary of injection activities, wells utilized, duration and dates of injection, injected volume, and concentration of injectates for the "Super 8" field experiment.

\begin{tabular}{|c|c|c|c|c|c|c|}
\hline $\begin{array}{l}\text { Injection } \\
\text { activity }\end{array}$ & $\begin{array}{l}\text { Injection well } \\
\text { numbers }\end{array}$ & Date ${ }^{[\mathrm{time} e}$ & $\begin{array}{l}\text { Duration } \\
\text { [days] }\end{array}$ & $\begin{array}{c}\text { Injected } \\
\text { volume } \\
\text { [L] }\end{array}$ & $\begin{array}{c}\text { Reagent } \\
\text { concentration } \\
{[\mathrm{mM}]}\end{array}$ & $\begin{array}{c}\text { Isotope } \\
\text { enrichment } \\
{[\%]}\end{array}$ \\
\hline \multicolumn{7}{|l|}{ Precursory } \\
\hline \multicolumn{7}{|l|}{ tracers: } \\
\hline $\mathrm{NaBr}$ & CA02 & 10-Aug-10 [1603] & 0.58 & 400 & $5.8\left[\mathrm{Br}^{-}\right]$ & -- \\
\hline $\mathrm{H}_{2}{ }^{18} \mathrm{O}$ & CG04 & $15-A u g-10$ [1750] & 0.53 & 350 & -- & $23\left[{ }^{18} \mathrm{O}\right]$ \\
\hline \multicolumn{7}{|l|}{ Posterior } \\
\hline \multicolumn{7}{|l|}{ tracers: } \\
\hline $\mathrm{NaBr}+\mathrm{D}_{2} \mathrm{O}$ & CA02 & $20-N o v-10^{[1000]}$ & 0.58 & 400 & $5.8\left[\mathrm{Br}^{-}\right]$ & $500[\mathrm{D}]$ \\
\hline \multicolumn{7}{|l|}{ Bicarbonate - } \\
\hline \#1 start & CA01-CA03 & 16-Aug-10 [0630] & 11 & 6000 & $50\left[\mathrm{HCO}_{3}^{-}\right]$ & 500 [D] \\
\hline \#1 end & " " & $27-A u g-10^{[1400]}$ & & & & \\
\hline \#2 start & " " & 29-Aug-10 [1200] & 10 & 6000 & $50\left[\mathrm{HCO}_{3}^{-}\right]$ & 500 [D] \\
\hline \#2 end & " " & 7-Sept-10 [1912] & & & & \\
\hline \multicolumn{7}{|l|}{$\frac{\text { Acetate - }}{\text { Bromide: }}$} \\
\hline \#1 start & CG01-CG10 & 23-Aug-10 [1256] & 14 & 2200 & $50\left[\mathrm{CH}_{3} \mathrm{COO}^{-}\right]$ & -- \\
\hline \#1 end & " " & 7-Sept-10 ${ }^{[0700]}$ & & & $20\left[\mathrm{Br}^{-}\right]$ & \\
\hline \#2 start $^{* *}$ & " " & 13-Sept-10 [1845] & 9 & 1500 & $50\left[\mathrm{CH}_{3} \mathrm{COO}^{-}\right]$ & -- \\
\hline \#2 end & " " & 22-Sept-10 [1718] & & & $20\left[\mathrm{Br}^{-}\right]$ & \\
\hline
\end{tabular}

"Concentration/enrichment within the injection tank. ${ }^{* * *}$ Tank \#2 injection was initially started on 9-Sept-10; however, a closed injection valve prevented flow from the tank; injection was re-started on 13-Sept-10, as indicated. 
Figures. Long et al. GCA Submittal

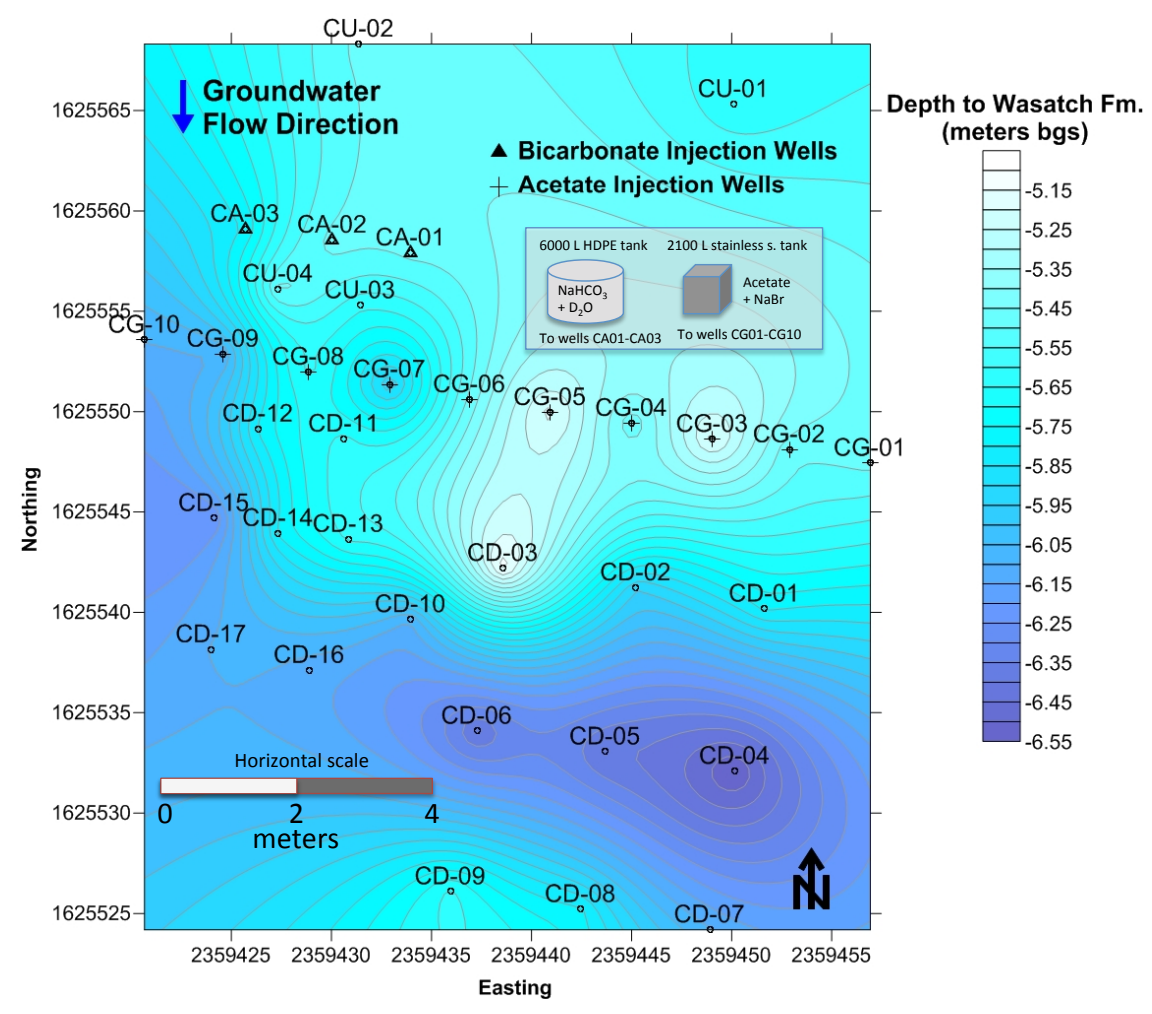

Figure 1: Well layout for Plot C, site of the Super 8 field experiment. The Rifle field site location is provided in Williams et al., (2011). Inset shows the two tanks containing the separate injectates used in the experiment. 

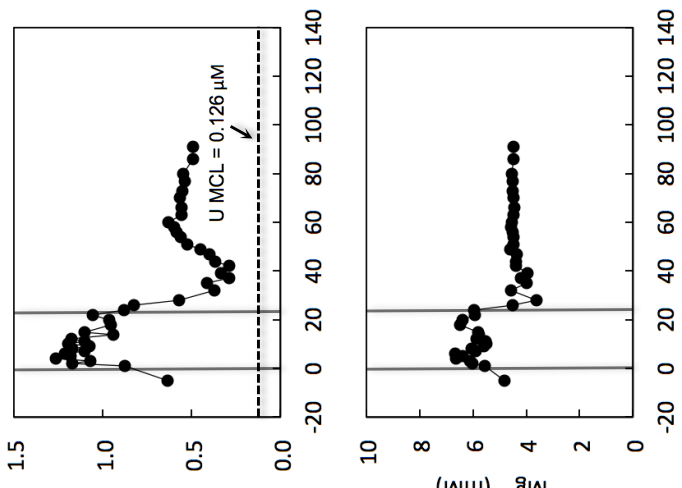

(wr) $(I \Lambda) \cap$
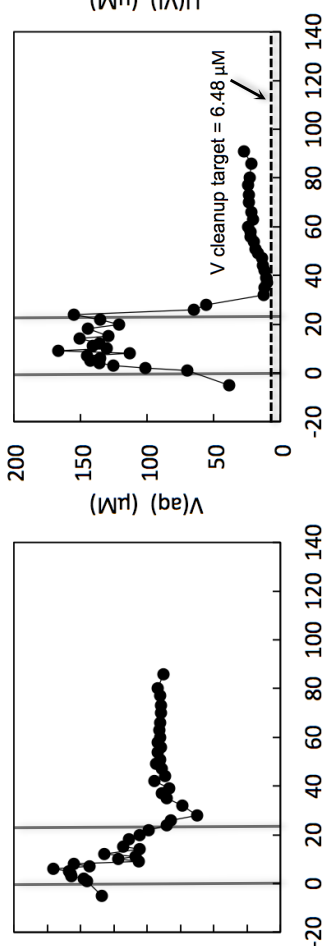

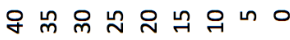

(wr) (be)uw

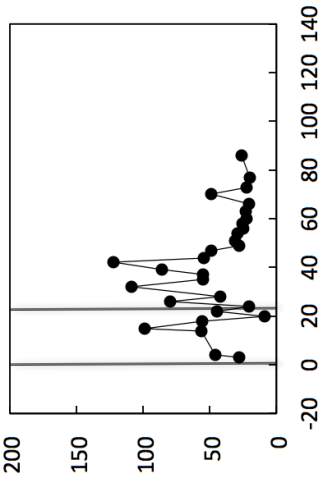

(Wr) (II)
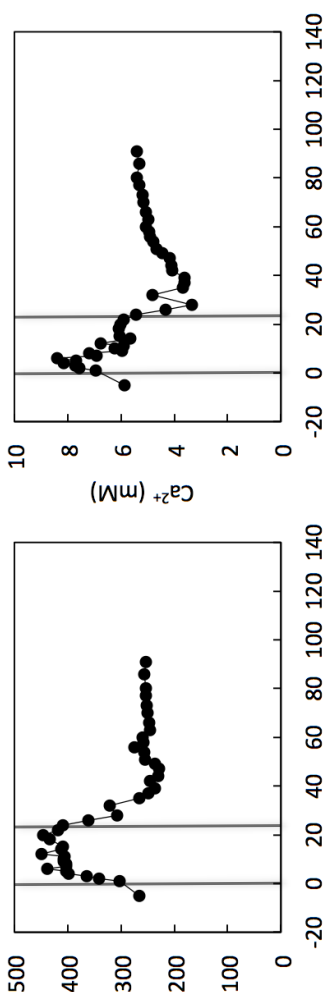

(wri) + त्र

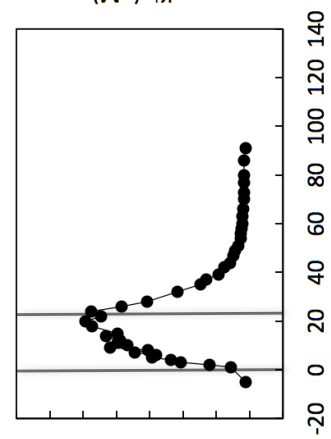

옷응의 을 유윽

(Ww) +eN 

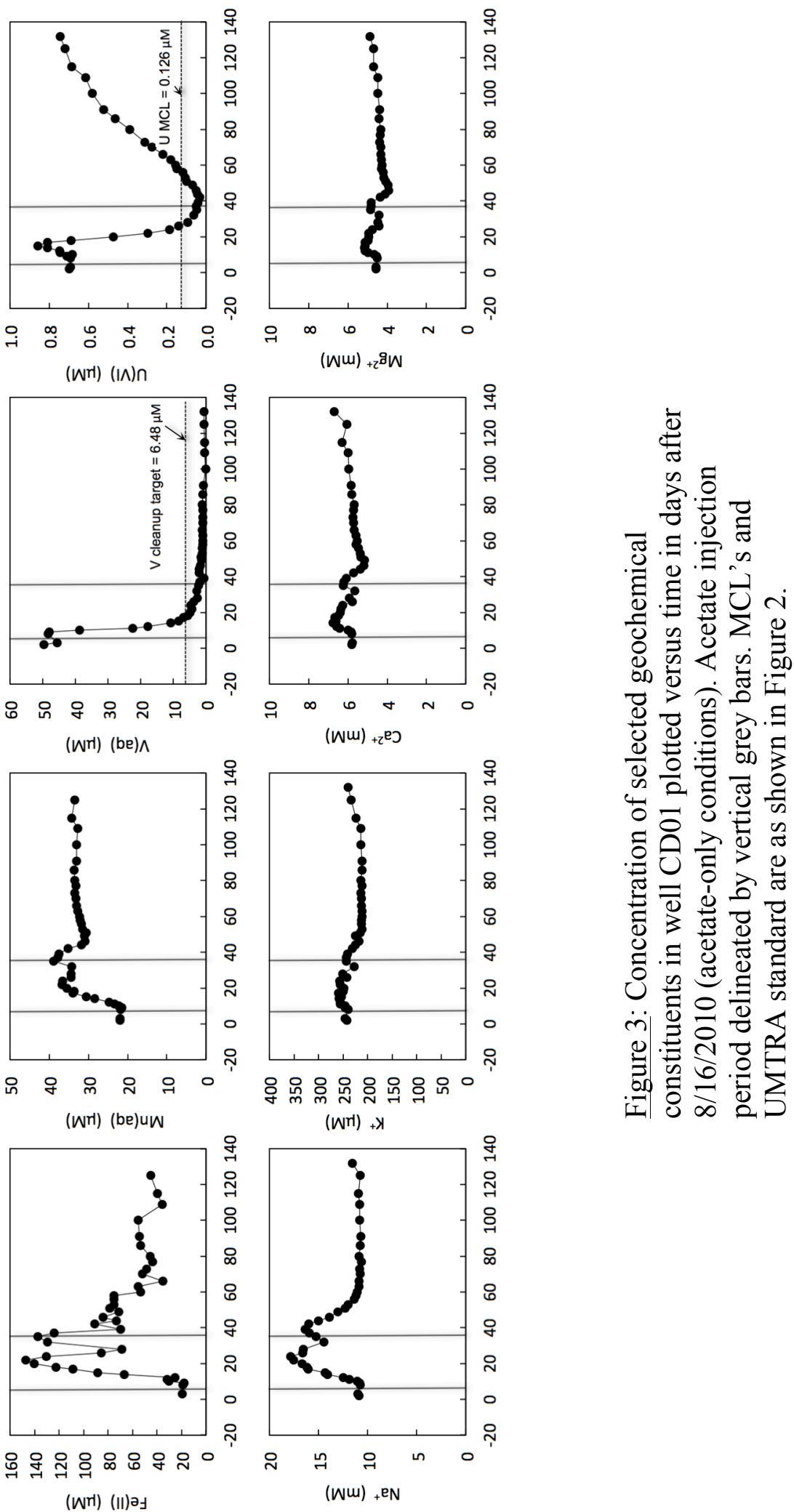

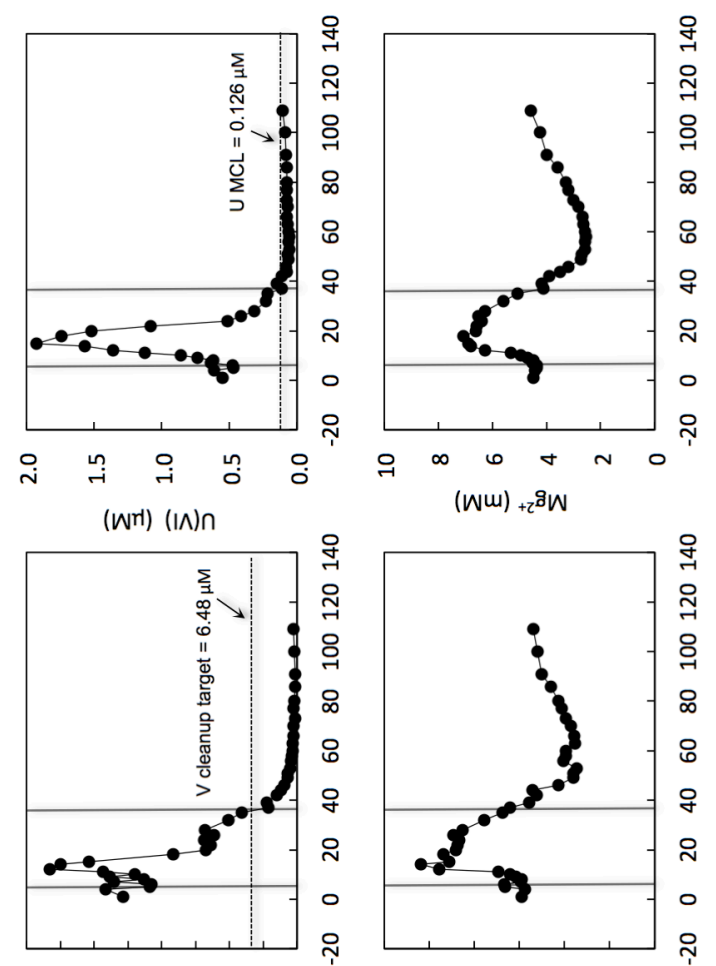

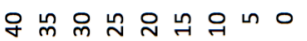

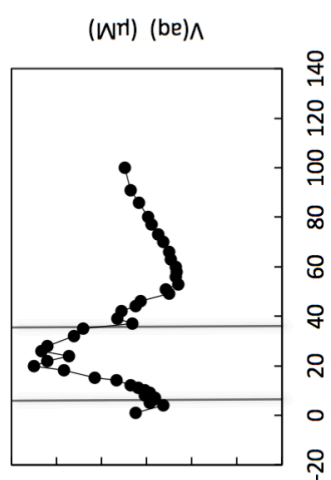

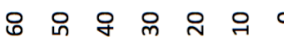

(wri) (be)uw
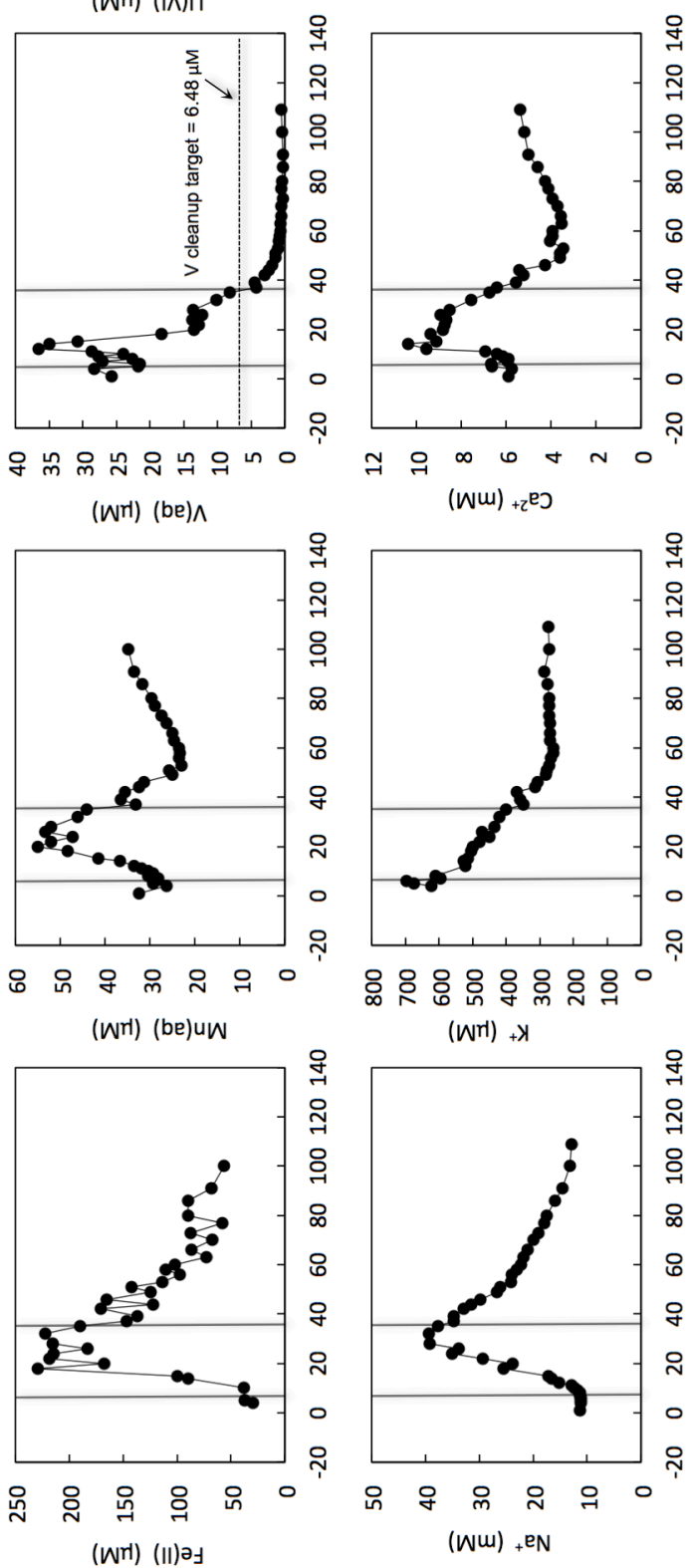

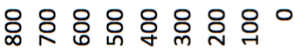
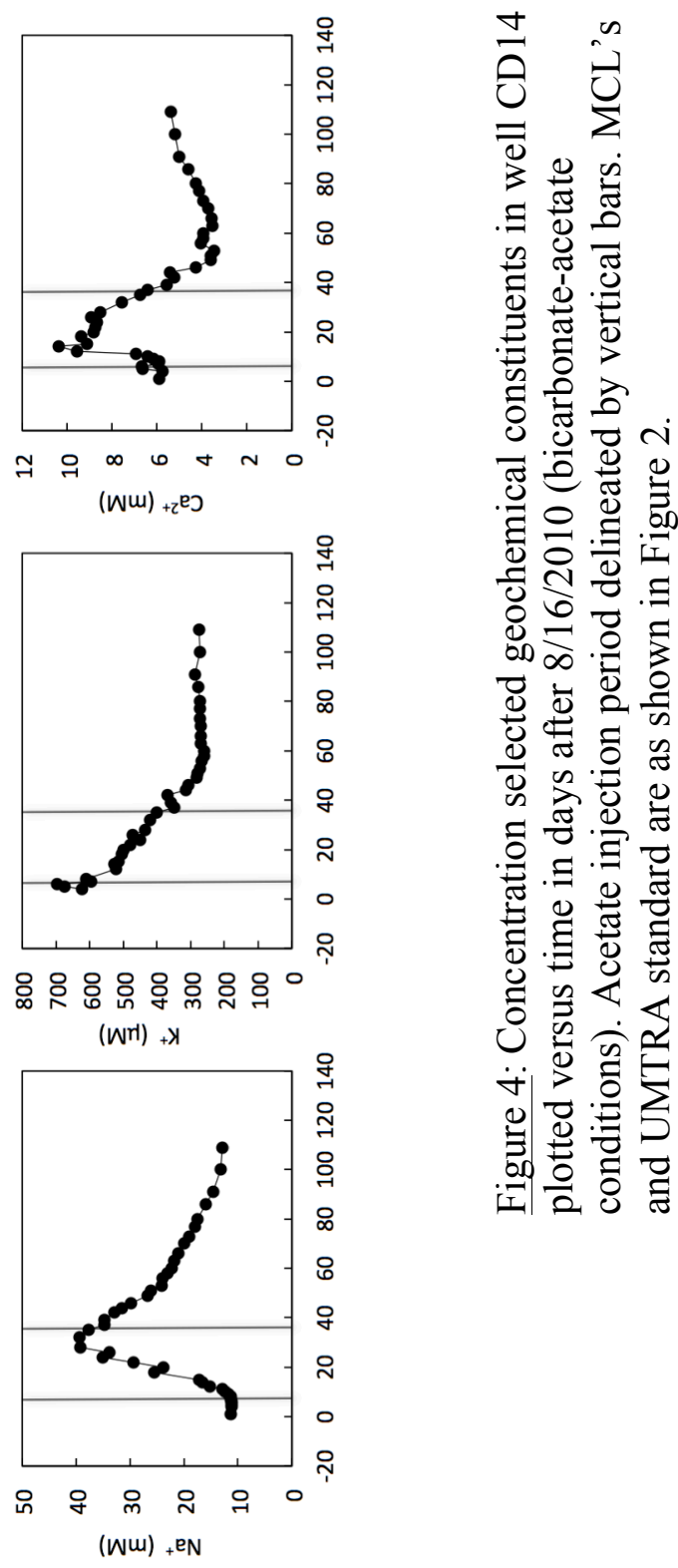
A.

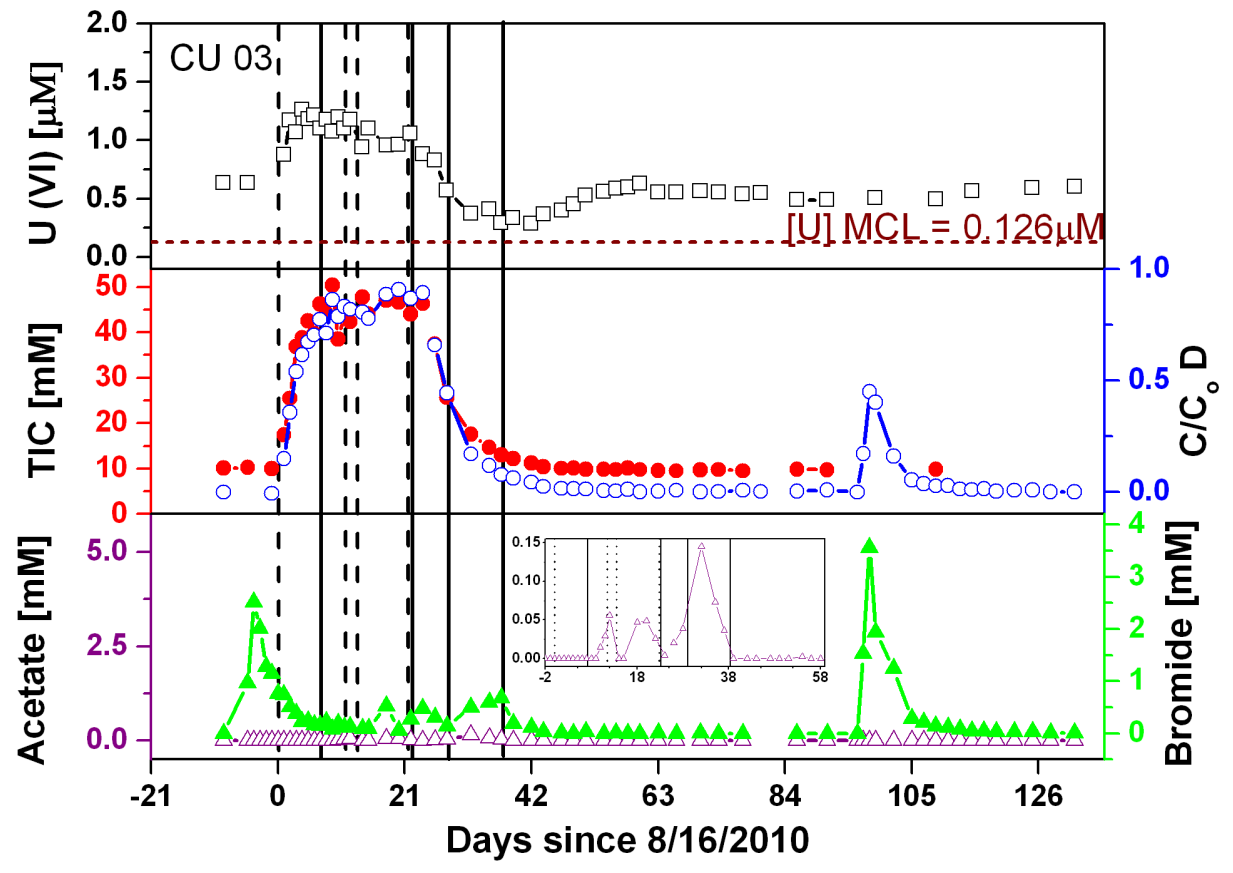

B.

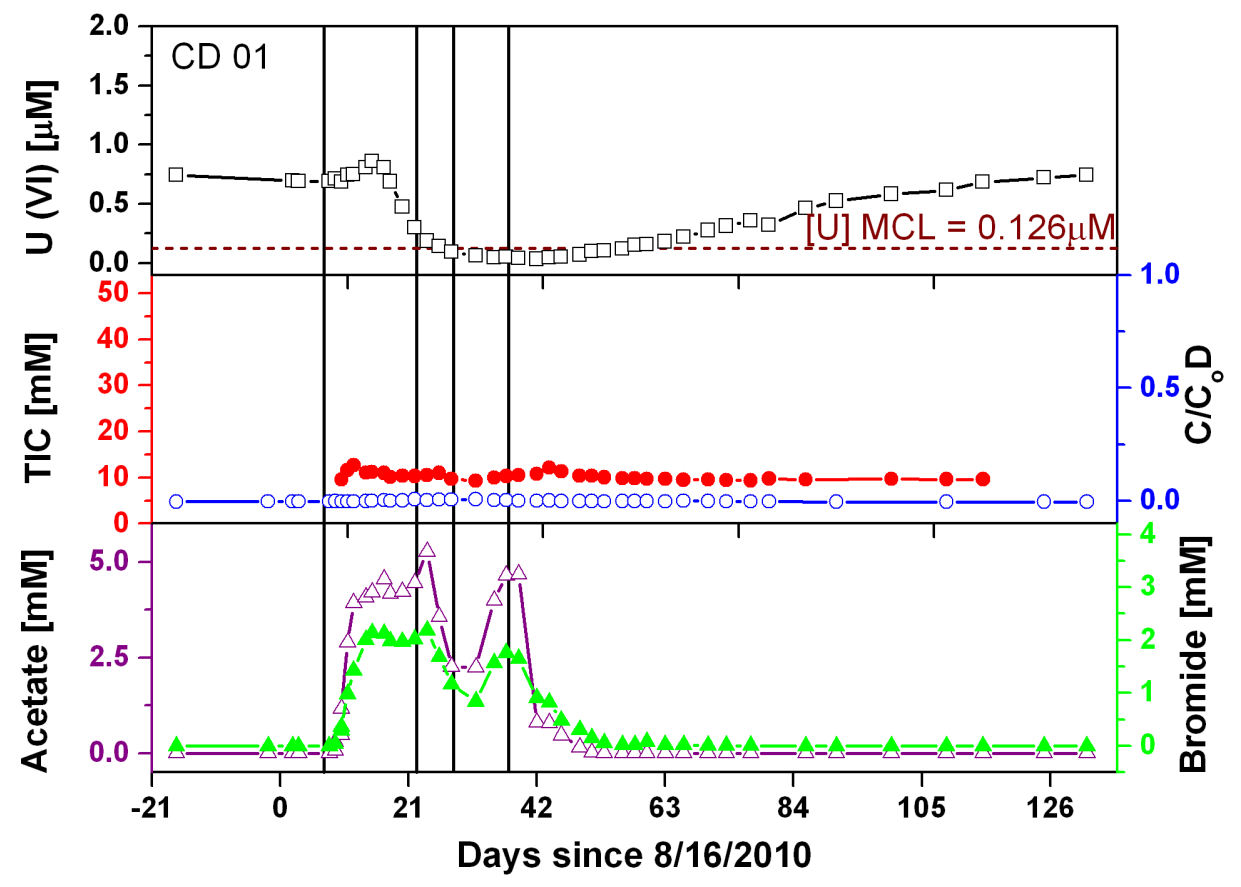




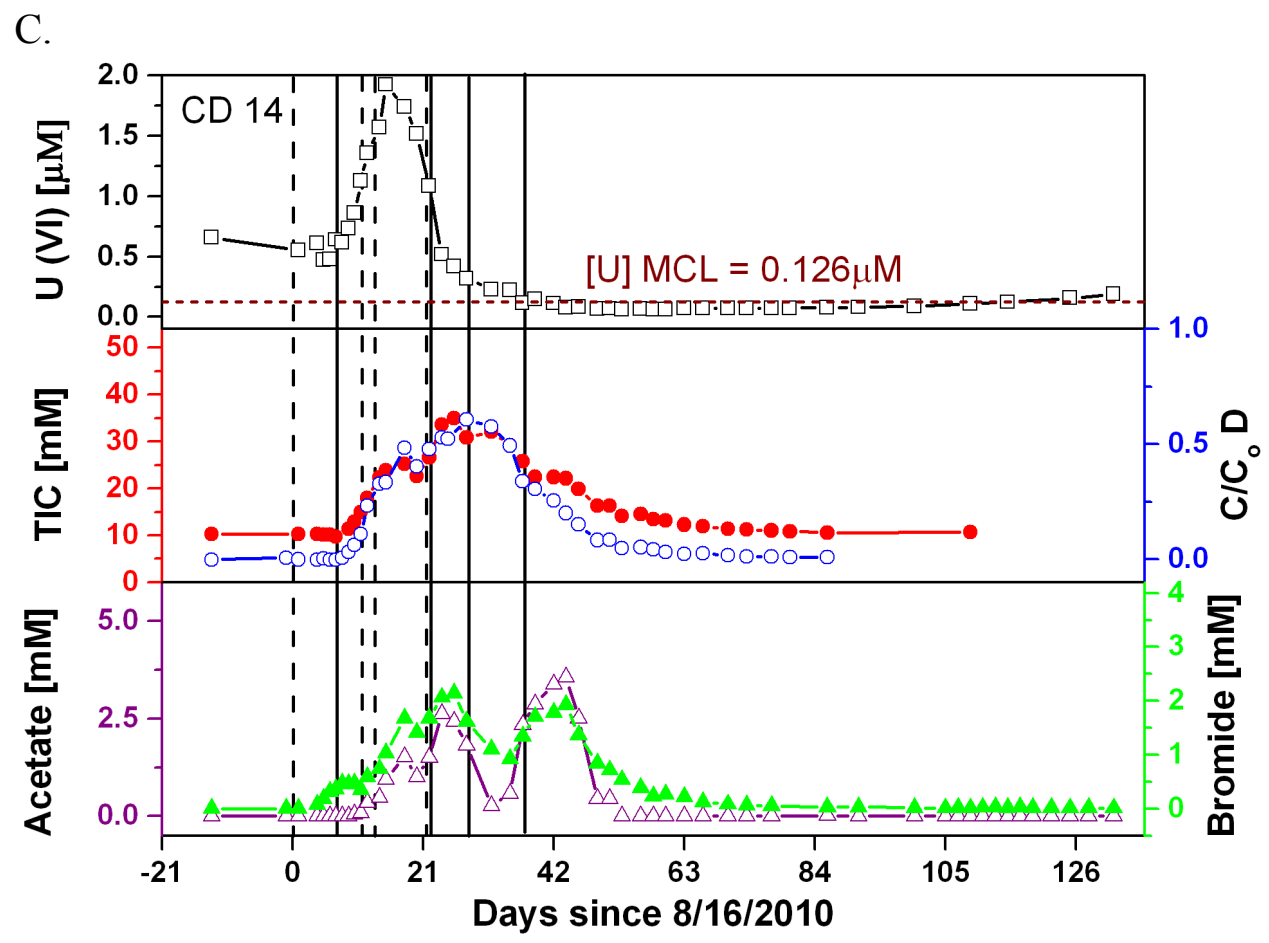

Figure 5: Comparison of the behavior of aqueous U(VI), D and bromide tracers, acetate, and total inorganic carbon (TIC) in CU03 (A), CD01 (B) and CD14 (C). TIC concentrations result from the $\mathrm{NaHCO}_{3}$ injection (start and stops represented by dashed vertical lines). Starts and stops for acetate injection denoted by vertical grey bars (see Table 1). The inset in A. shows acetate with an expanded scale where acetate is above detection. MCL is as shown in Figure 2. 


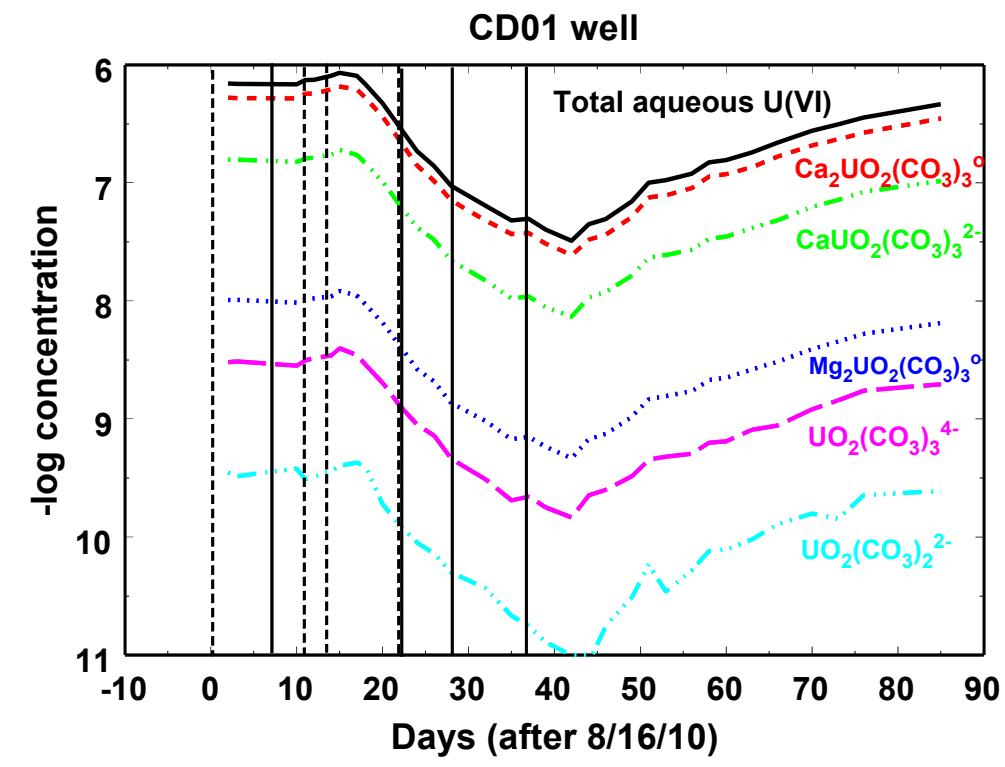

A.

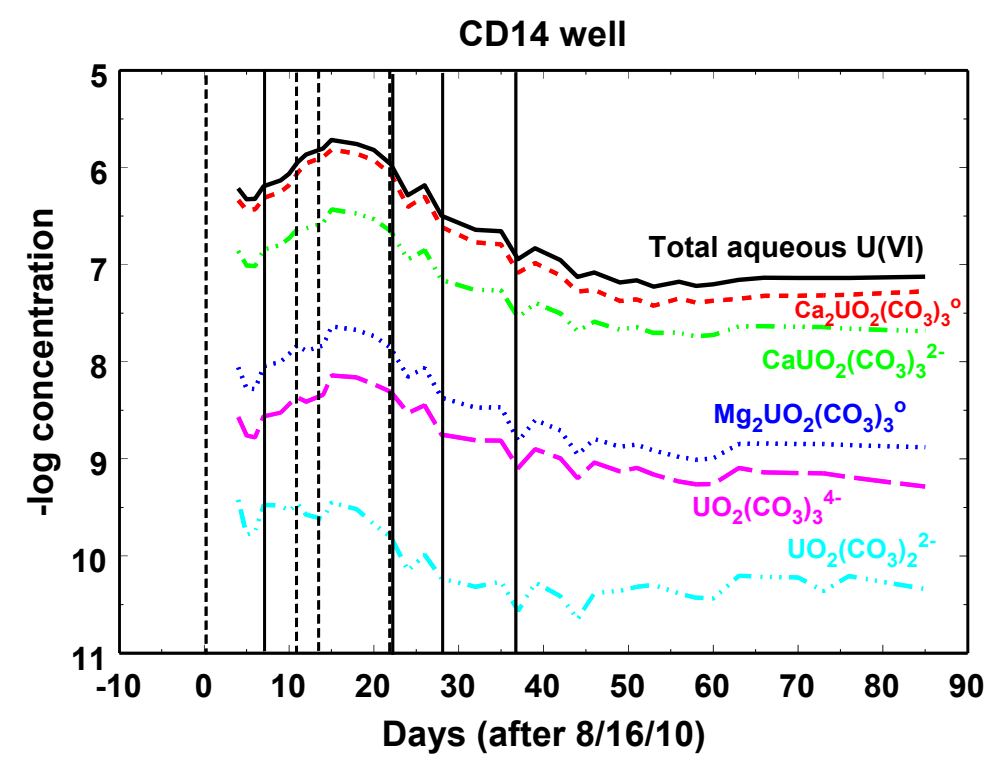

B.

Figure 6. Plots of the total concentration of dissolved U and calculated U(VI) aqueous species concentrations as a function of time in wells CD01 (A) and CD14 (B). Vertical lines are the same as in Figure 5. See "Materials and Methods" for details on calculations. 


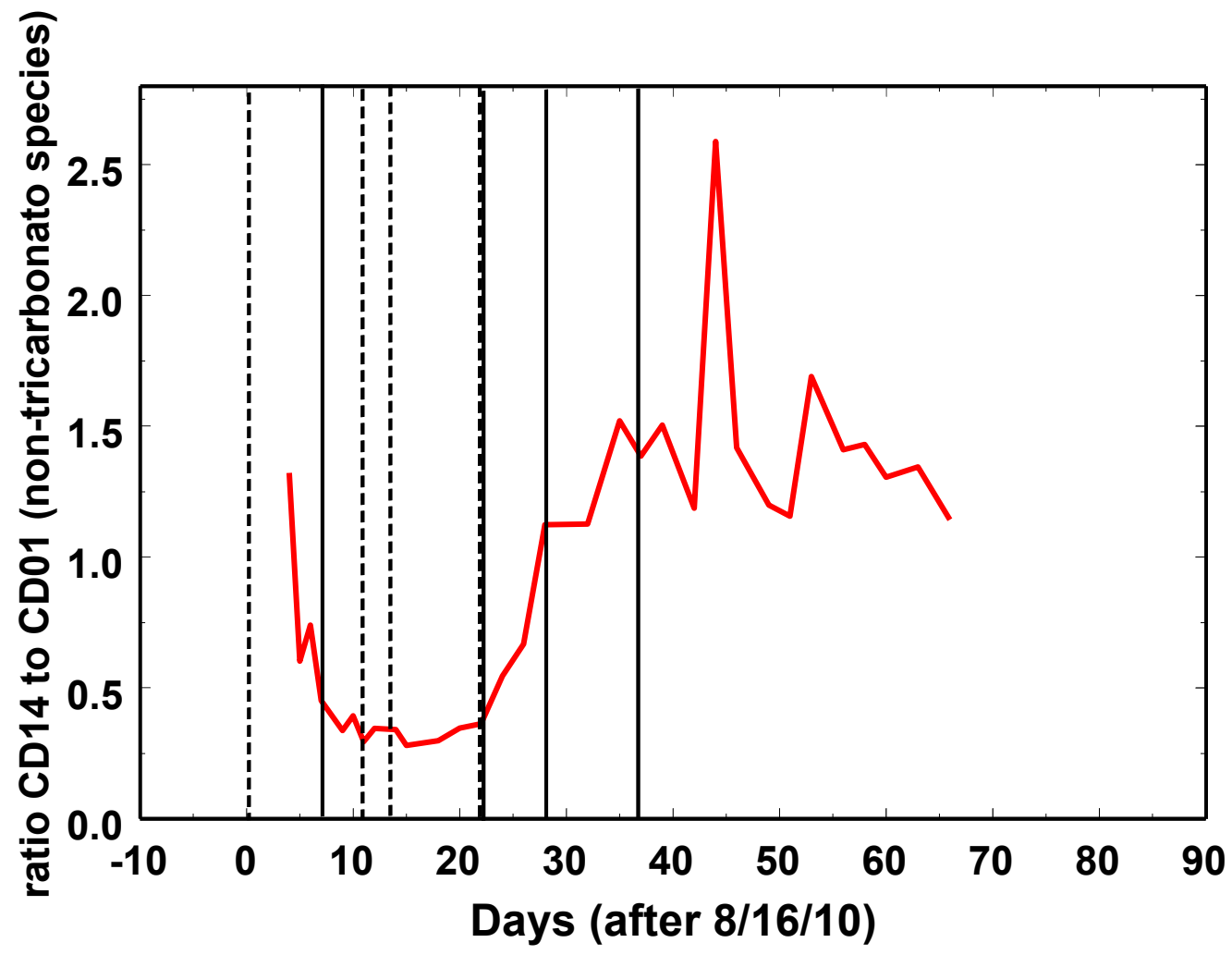

Figure 7. Plot of the ratio of the calculated fractional contribution of non-tricarbonato species to total dissolved $\mathrm{U}$ in well $\mathrm{CD} 14$ versus well $\mathrm{CD} 01$ as a function of time. Vertical lines are the same as in Figure 5. 
Sulfate Reducers

Metal Reducers

Fermenters

CD-01

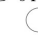

CD-04
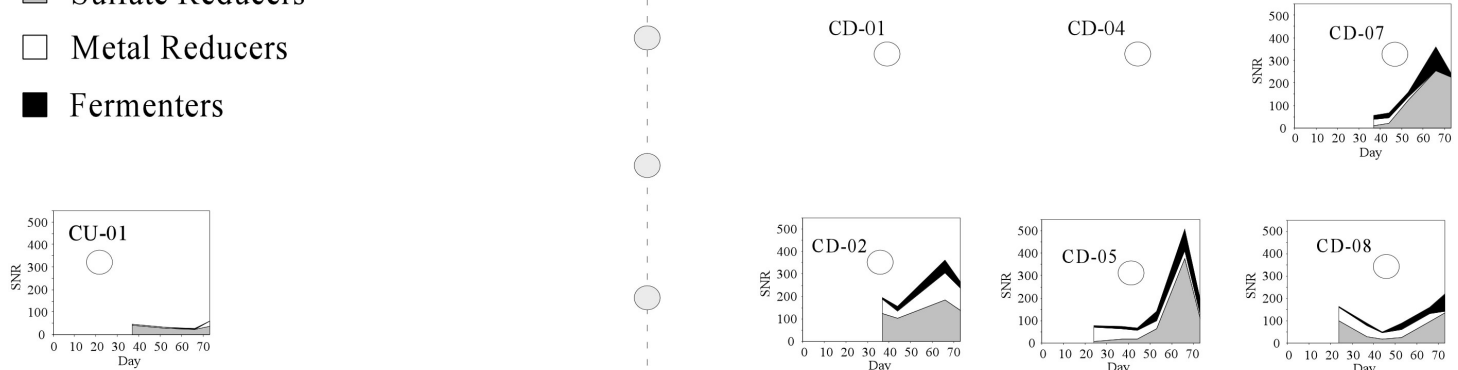

CU-02

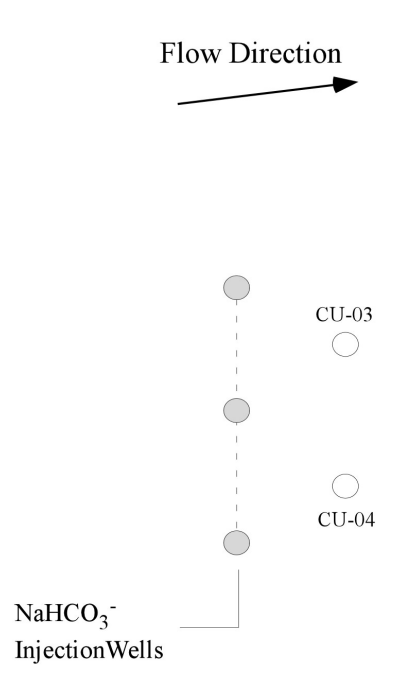

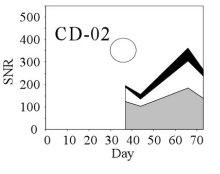
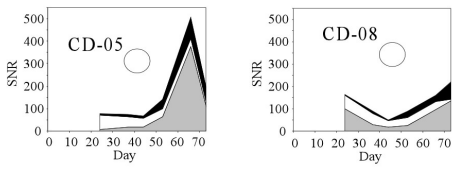

CD-03

CD-06
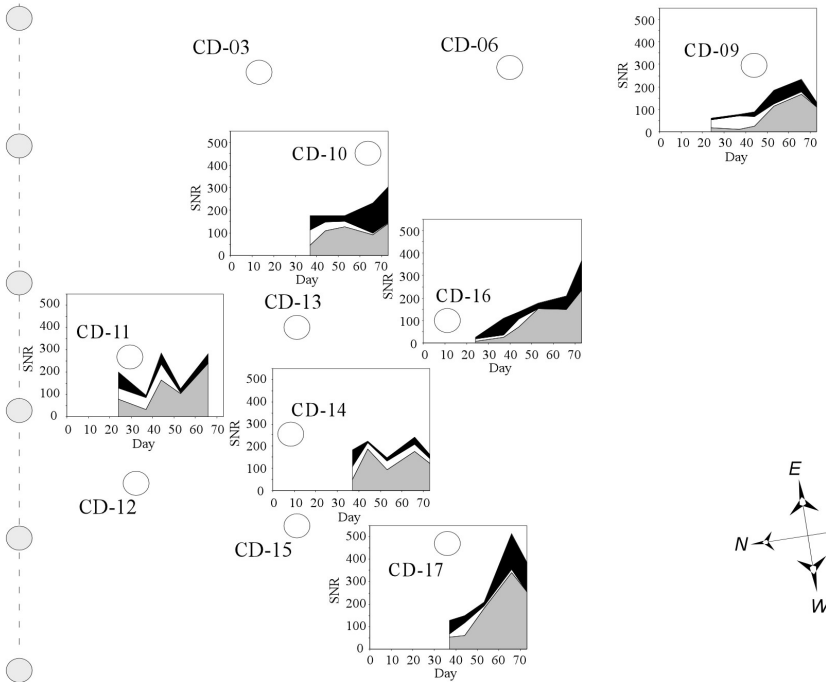

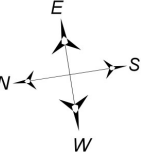

Figure 8. Spatial distribution and time variation of metal reducers, sulfate reducers and fermenters in selected wells based on microarray data. The Y-axis scale on graphs is the signal to noise ratio, SNR, $\mathrm{X}$-axis scale is days since the start of the experiment. All graphs have the same scales (X-axis 0-70 days, Y-axis 0-500 SNR). Charts show stacked results for the three functional groups of bacteria. Wells CD11, CD14 and CD16 represent bicarbonate-acetate impacted wells as compared to CD02, CD05, and CD07 as acetate-only wells. Well CD-17 was missed by bicarbonate but was impacted by acetate. Day zero was 16 August 2010. 

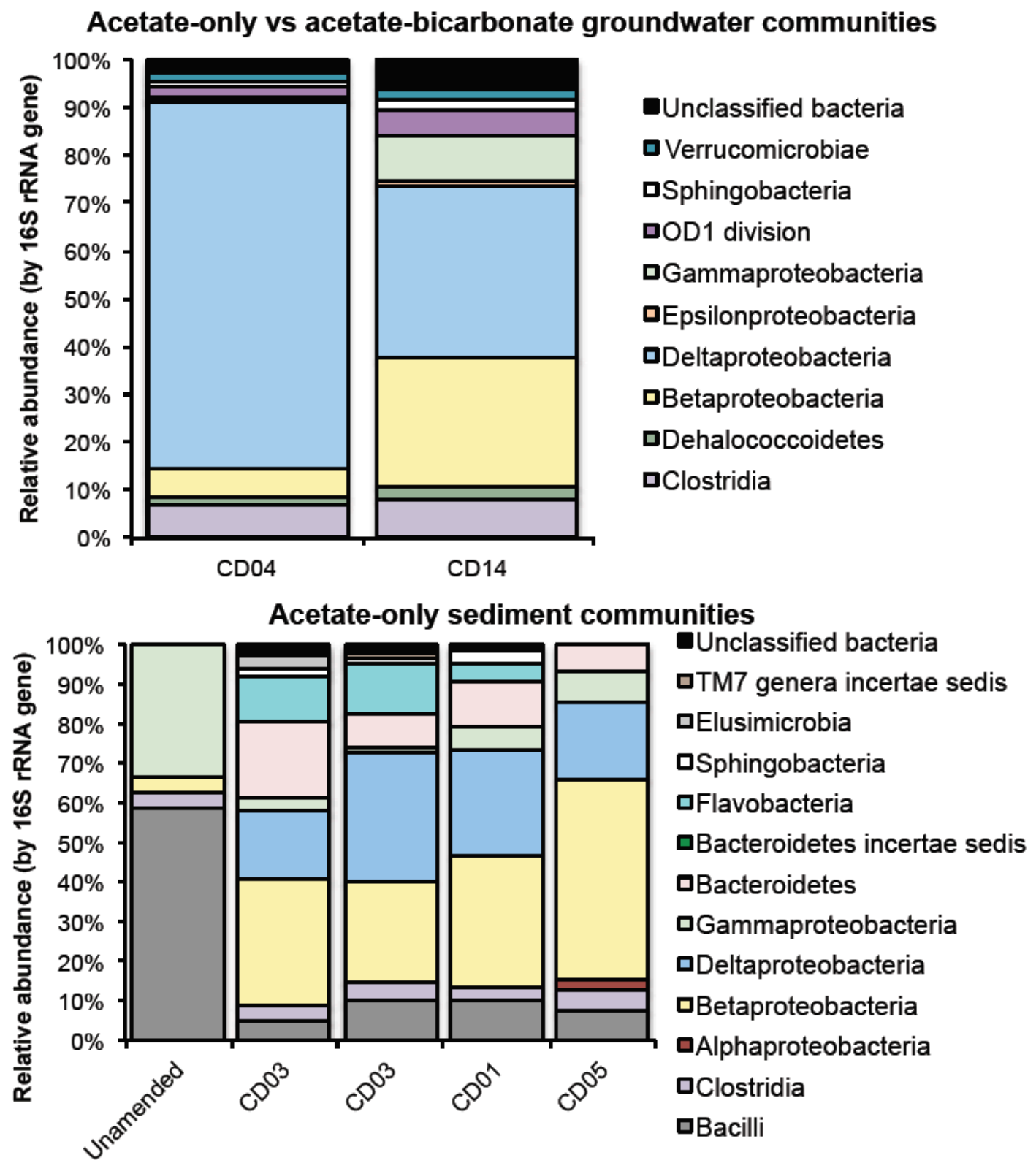

Figure 9. 16S rRNA gene clone library results (topmost chart) summarized to the class level for groundwater samples from wells CD-04 (acetate-only) and CD14 (bicarbonateacetate) on 16 September 2010. For comparison, reconstructed 16S rRNA gene results are given below for unamended sediment and sediment from 4 replicate flow-through columns collected from acetate-only wells on $12^{\text {th }}$ and $19^{\text {th }}$ of September 2010 (CD03, CD01 and CD05). Reconstructed sequences used were present at $\geq 1 \%$ relative abundance. 


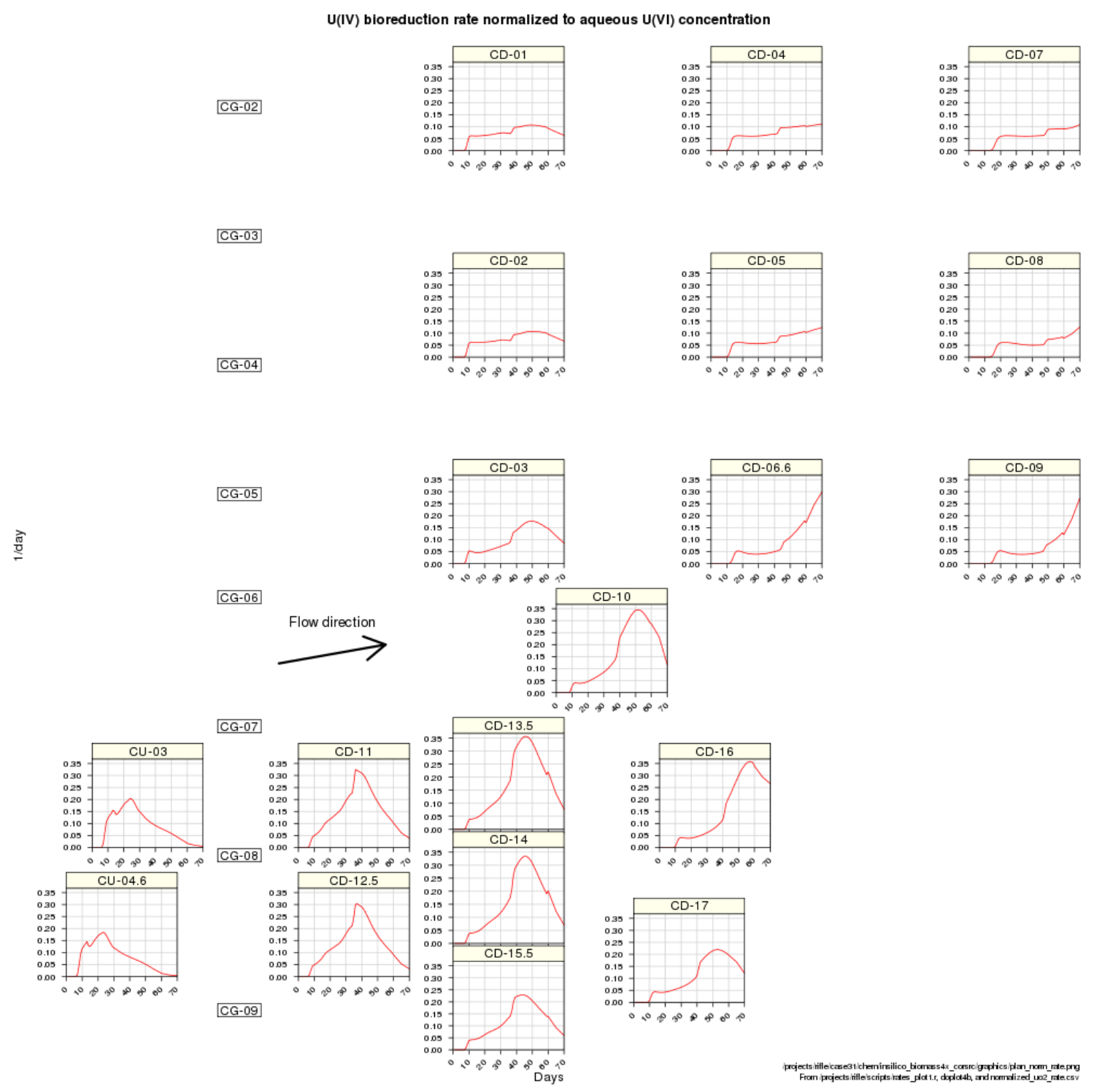

Figure 10. Plots of the simulated U(VI) reduction rate normalized to U(VI) concentration as a function of time across the experimental domain. $\mathrm{Y}$-axis values are $\mathrm{mol} \mathrm{L}^{-1} \mathrm{~d}^{-1}$ $\mathrm{mol}_{\mathrm{U}(\mathrm{VI})}{ }^{-1} \mathrm{~L}^{-1}$ or $\mathrm{d}^{-1}$.Well numbers with a digit after a decimal point (e.g., CD-13.5) indicate wells with discrete sampling ports ranging from 1 to $3 \mathrm{~m}$ above the base of the modeling domain (elevation $1612.85 \mathrm{~m}$ above MSL). The ground surface is $6.5 \mathrm{~m}$ above the base of the modeling domain. 